\title{
Floral Species as Environmental Quality Indicators in Jordan: High Salinity and Alkalinity Environments
}

\author{
Ikhlas Alhejoj ${ }^{*}$, Klaus Bandel2, Elias Salameh1 \\ ${ }^{1}$ Department of Environmental and Applied Geology, The University of Jordan, Amman, Jordan \\ ${ }^{2}$ Geologisch-Paläontologisches Institut und Museum Hamburg, Universität Hamburg, Hamburg, Germany \\ Email: ${ }^{*}$ ekl hjouj@yahoo.com, ${ }^{*}$ i.alhejoj@ju.edu.jo
}

Received 25 November 2014; accepted 10 April 2015; published 22 May 2015

Copyright (C) 2015 by authors and Scientific Research Publishing Inc.

This work is licensed under the Creative Commons Attribution International License (CC BY). http://creativecommons.org/licenses/by/4.0/

cC) (i) Open Access

\begin{abstract}
In this study the occurrence and ecology of plant assemblages are investigated, mainly for use as indicator plants of saline grounds in several locations in Jordan. High alkalinity and $\mathrm{H}_{2} \mathrm{~S}$-rich water tolerant species of plants are also discussed. Plants growing on salty grounds have distinct composition regarding their place in the taxonomic system. Plant assemblages and their degree of tolerance to salinity as in Karama area in the Jordan Valley are found to be distinct from that of Azraq Sabkha (Cental Jordan) with salt-tolerant flora. Karama area provides the living space for Mesembryanthemum on the saltiest ground, Suaeda further up on wetter surrounding and Salicornia succeeding on moist and less salty grounds. Drier places with rather salty grounds have bushes of Arthrocnemum, while slightly less salty places are preferred by Tamarix tetragyna. When Prosopis bushes appear, salt is only present periodically in the ground, as is also the case with Atriplex halimus and Capparis. In Azraq the former beach of a temporal lake is characterized by two species of Spergularia in its saltier parts and by Tamarix passerinoides. It was recognized that Tamarix, Phragmites, Chenopodium, and Inula represented alkaline water tolerant plants. The study concludes that the salt concentration in the ground is reflected in the composition of the flora growing on it. On the other hand, plants are also found vulnerable to fluctuation in the salt concentration of their environments with different resistance degrees. This makes them excellent bioindicators of salty environments.
\end{abstract}

\section{Keywords}

Bioindicators, Alkalinity Tolerant Plants, Halophyts, Environmental Quality, Karama, Azraq

\footnotetext{
${ }^{*}$ Corresponding author.
}

How to cite this paper: Alhejoj, I., Bandel, K. and Salameh, E. (2015) Floral Species as Environmental Quality Indicators in Jordan: High Salinity and Alkalinity Environments. Journal of Environmental Protection, 6, 494-514. 


\section{Introduction}

Halophytes represent plants survive and grow to complete their life cycle with at least 200 mmhos/cm salt [1] [2]. Halophytes come into contact with saline water through the roots. A salt tolerating plant that can grow on a soil with more than $0.5 \%$ salt of the dry weight is also considered to represent a halophyte [3]. Salt concentrations in the soil are measured in promille (1\%o equals $1 \mathrm{~g} / \mathrm{L})$. They are considered as oligohaline (Greek oligosfew) in case the plant tolerates concentrations of $0.5 \%$ - 5\%, mesohaline (Greek meso-middle) with plants tolerating $5 \%$ o to $18 \%$ of salt concentrations, and polyhaline (Greek poly-many) with a soil salt content of up to $30 \%$ in their surrounding [4]-[6].

Salt contents of less than $0.5 \%$ of soil dry weight have halophytes growing in it. It is not defined originally which kind of salt is dissolved, but it is understood that it is predominantly NaCl. Plants growing here are holophile, while those avoiding it are halophobe [1]. Relatively few plant species are halophytes-perhaps only $2 \%$ of all plant species. The large majority of plant species represents glycophytes which are growing with fresh water as available to their roots. They are not salt-tolerant and are damaged fairly easily by high salinity.

Soil salinity is the salt content in the soil. Salination is the process of increasing the salt content. Salt is a natural element of soils and water. Salination can be caused by natural processes such as mineral weathering or the gradual withdrawal of an ocean which may have occurred during past geologic periods. It can also be caused by artificial processes such as irrigation. The excess accumulation of salts is typically most pronounced at the soil surface. Salts may rise to soil surface by capillary transport from a salt-laden water table and then accumulate due to evaporation. As soil salinity increases, salt effects can result in degredation of soil and vegetation. The ions responsible for salination are: $\mathrm{Na}^{+}, \mathrm{K}^{+}, \mathrm{Ca}^{2+}, \mathrm{Mg}^{2+}$ and $\mathrm{Cl}^{-}$and $\mathrm{SO}_{4}^{2-}$. As the $\mathrm{Na}^{+}$(sodium) predominates, soils can become sodic. Over long periods of time, as soil minerals weather and release salts, these salts are flushed or leached out of the soil by drainage water in areas with sufficient precipitation. In addition to mineral weathering, salts are also deposited via dust and precipitation. Thus, especially in dry regions salts may accumulate, leading to naturally saline soils. Human practices can increase the salinity of soils by the addition of salty irrigation water.

Many halophytes are facultative halophytes and can grow in saline and nonsaline habitats. Others are obligate halophytes which can survive only in saline environments as for example Salicornia, Suaeda, and Mesembryanthemum in this study. The roots can tolerate the salts and store the absorbed salts as is the case of Prosopis farcta in this study. Prosopis farca carries out Sodium retention by its roots. Leave bristles in Atriplex and Limonium can store salt and the plant can get rid of the salt by discarding it.

Leaves as storage of salt are found in Suaeda, Spergularia, and the stem stores salt in case of Salicornia. Here the concentration of salt remains up to the end of the life cycle which is also the case in Juncus maritimus [4].

Salt accumulators such as Salicornia absorb salts throughout the growing season and die when a lethal level is reached. At this stage, the life cycle is completed. Salt accumulators, such as saltbush (Atriplex) and tamarisk (Tamarix), have specialized cells called salt glands located on the surfaces of their leaves, used for storing excess sodium chloride [5] [7]. As glands fill with salt they eventually burst, releasing salts that form a crystalline coating on leaves. The crystals fall or are dissolved by rain, which returns the salt to the soil.

A high salt concentration in special vacuoles is found in typical succulent halophytes, such as Mesembryonthemum [8]. Some salt accumulators avoid salt stress by minimizing salt concentration and concentrating it in special leaves, as is well seen in Spergularia marina [4].

The method to utilize plants as indicators of the environmental conditions is based on the principle that each aquatic plant species has different sensitivity to environmental stress (e.g., pollution and salinity) and the tolerance is usually limited so if the flora is known, the environmental quality can be predicted [9] [10]. Plants are good indicators because they are sessile and can not move away and escape from the conditions of the water stress so their presence or absence gives information about the water status and the reaction and respond of these plants can be used as environmental indicator and thus as biomonitors.

The objective of this study focuses on the use of plants as bioindicator of salty environments in Jordan, which lies in the semi arid climate zone resulting in increased salinity levels in its water and environments. Furthermore, the occurrences of characteristic plants in especial enviromantal conditions such as high pH value are also discussed. Characteristic plants growing in different environments were studied, mainly during the winter and springs seasons of the years from 2010 to 2014.

The study locations cover Zarqa River, Azarq, Karama (in the Jordan Valley) and Maqarin areas (Figure 1). 


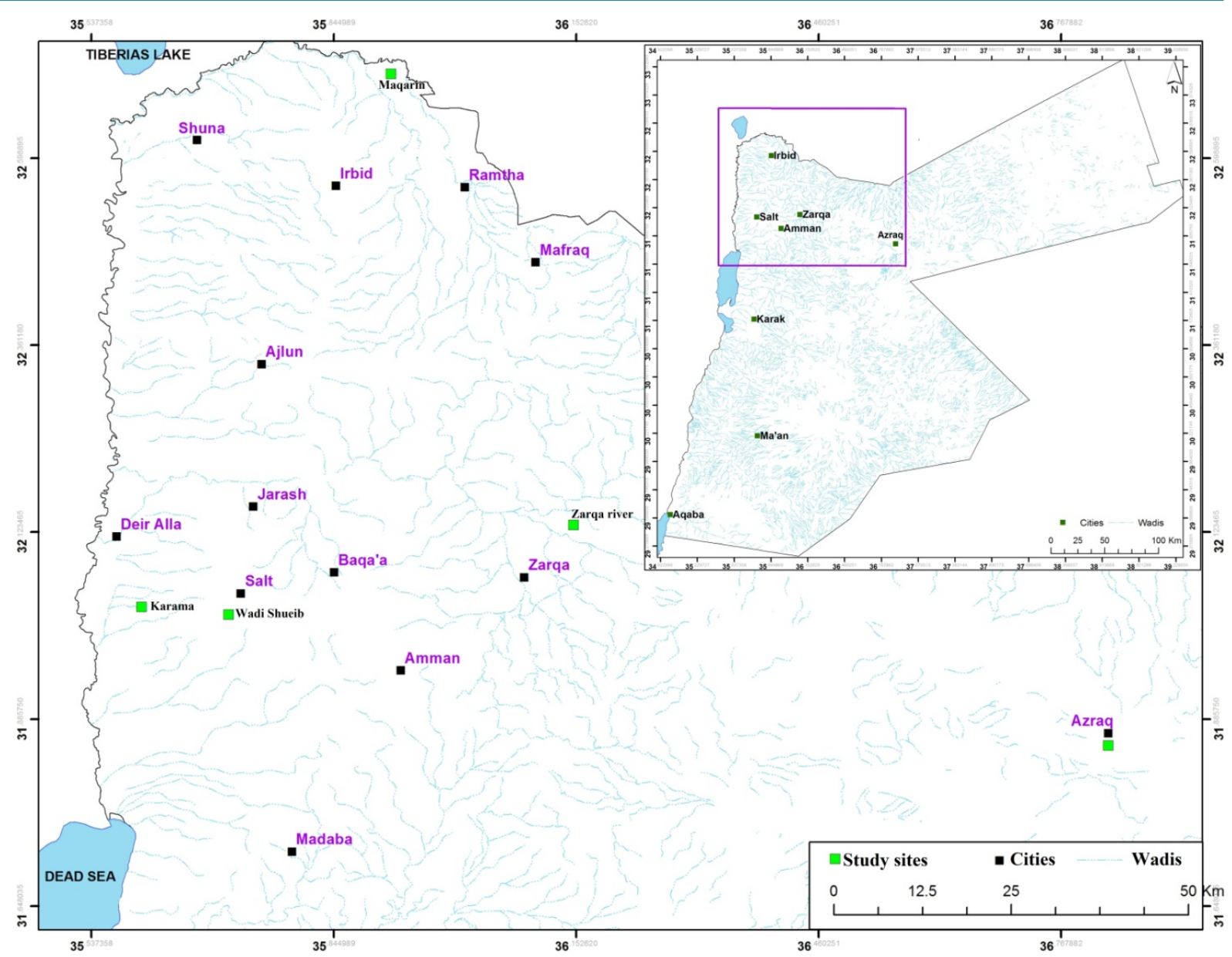

Figure 1. Location map of the study area with the drainage system, main cities and towns.

\section{Discussion of Localities and Plants}

Salty ground in Jordan can be caused by dry desiccating environment in which minerals dissolved in ground and surface water, and become enriched due to evaporation. Mineral content may be enriched also due to long migration paths of the water in the underground on its way to the surface or dissolution of evaporates deposits. In Azraq subsurface water comes to the surface through springs with high mineral content as a result of dissolution of evaporates from the ground. They are then concentrated further by evaporation.

Spring water used also to fill a lake at the western margin of the Azraq basin, but it was destroyed and dried out in the $90 \mathrm{~s}$ of the $20^{\text {th }}$ centery. After that an artificial fresh water lake has been created.

The source of salt in the salty ground in the Jordan Valley near Karama is derived from leaching of a salty deposit covering the area. This water comes from artesian springs and collectes in the reservoir lake behind Karama Dam to which fresh flood flows are added. The margins of that lake and the flood flats of the Karama Reservoir are thus influenced by brackish water arising from springs and by the fresh water collected in the lake.

Thermal springs enriched in minerals influence the surrounding soil. The first is an artesian well in the lower Wadi Zarqa. Here the discharged water have passed through the gypsiferous Triassic sequence and has taken up a mineral load including $\mathrm{H}_{2} \mathrm{~S}$. The second is a cold water spring in Maqarin area producing brackish high-alkaline water with a $\mathrm{pH}$-value of more than 12.

The plants which are encountered to grow next in these localities resemble each other in their tolerance to salinity. Seen in regard to their systematic composition they display considerable differences, and also their mode of growth is not the same. They are considered as halophytes in case the soil on which they grow contains more than $0.5 \%$ salt in dry weight as suggested by Albert 1982 [4] who had introduced the term.

Some plants are distinct indicators for salty grounds on which they grow. In the surrounding of Karama Re- 
servoir-Lake the flora on saline soil is characterized by Salicornia, Arthrocnemum, Mesembryanthemum and Suaeda which are only present in salty ground. Others can tolerate much higher salinity but also occur at places which have normal salinity, such as Phragmites and Phoenix. A third group occurs predominantly on non saline ground but may tolerate some salt such as Limonium, Capparis and Asteriscus. Some prefer salty ground but enter regions with only occasional salty conditions such as Atriplex and Cressa cretica. Quite a number of species tolerate fresh as well as slightly salty ground as Asteriscus, Trigonella, Prosopis farca, Paronychia argentea and Anthemis. A special case is the bush or small tree Tamarix in Jordan that tolerates all kind of moist grounds. Among them Tamarix passerinoides which prefers a different type of saltyness than Tamarix tetragya and Tamarix jordanica which preferes unsalty to fresh water even if polluted.

The composition of the flora that grows on salt ground at the margin of Azraq oasis is quite different. Here the species of herbaceous genus Spergularia are quite sensitive with the saltiest environment tolerated by Spergularia marina, the slightly less salty by Spergularia media. Less salty places provide environment for growth of the composite species of Aaronsohnia, Anthemis and Crepis and also the legumen Trigonella and the cruciferan Noetorularia.

Among the grasses other than the reeds Phragmites australis, Aelurops littoralis and Juncaceae, such as Juncus maritimus avoid salty ground. The plants growing on or below water in Jordan are Ruppia in brackish water and Myriophyllum in standing water of the Azraq lake, even with its low salt content and Lemna only on fresh water but avoiding pollution.

Tamarix among the Caryophyllales within the order Tamaricales holds shrubs and trees which are quite characteristic to Jordan. The tamarisk or salt cedar has a number of species which live in the dry areas of Eurasia and Africa. In Jordan the salt cedar exists with 4 - 5 species of which only three species are here recognized, $T$. jordanis, T. tetragyna, and T. passerinoides. Zohary (1972) [11] recognized even more than 10 species living in the region as shrub and trees. While Tamarix has small flowers and the flowers of the related Reaumuria are larger.

Tamarix can tolerate soil salinity and grows under adverse conditions with salty water or treated waste water or brines of de-saliniated water. The three species recognized here are Tamarix jordanis or palaestina that grows along rivers and, as noted here suround the ponds in Azraq Oasis, Tamarix tetragyna or nilotica which grows on salty grounds in the Jordan Valley (Figure 2(a)) and was found near Karama Revervoir lake and Tamarix passerinoides which is found on the eastern margin of the salty part of Azraq sabkha flats (Figure 2(b)). Tamarix tetragyna/nilotica likes more or less salty ground and forms solid bushes, of which the wood has been used in ancient times for copper smeltering in Wadi Feiynan.

Tamarix palaestina (in Zohary 1972, pl. 518 [11]) lives on water containing high percentages of chlorides, and closely resembles Tamarix jordanis, except for minute differences of flowers (Figure 3(a)). Also varieties of Tamarix nilotica are similar and may be intermediate among the aforementioned species (Zohary 1972 pl. 518, 519 and 521 [11]). The species of Tamarix resemble each other and may be distinguished by their leaves while the flowers are very similar but variable in shape and arrangement.

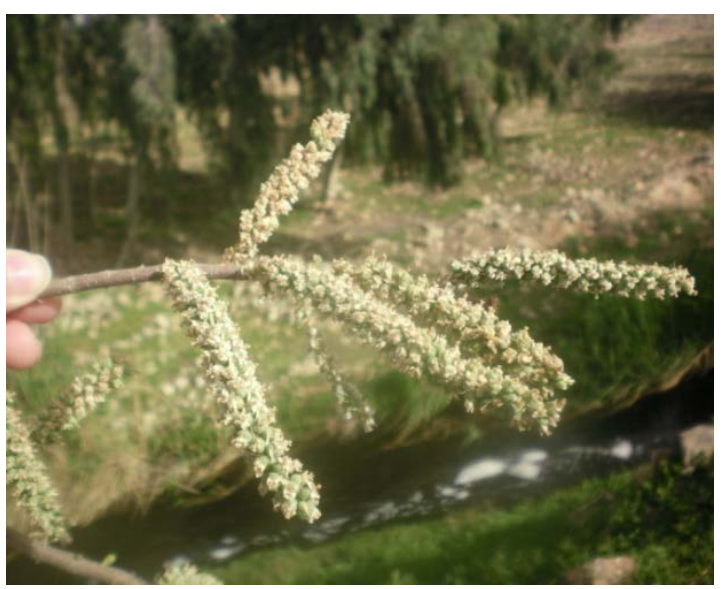

(a)

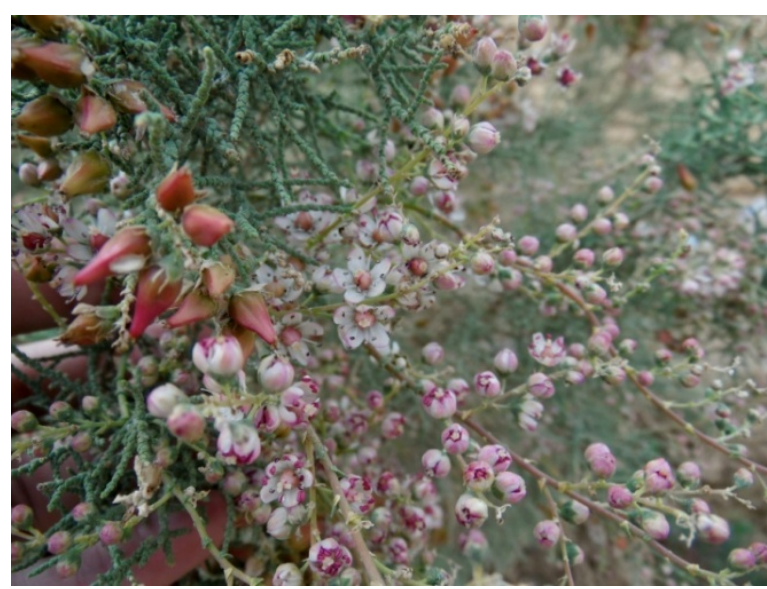

(b)

Figure 2. (a) Tamarix tetragyna, Zarqa River, 2013; (b) Tamarix passerinoides, Azraq 2014. 


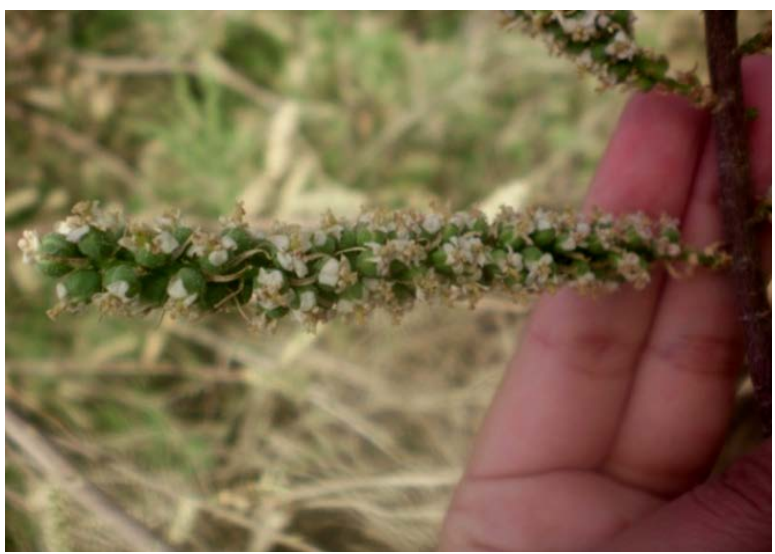

(a)

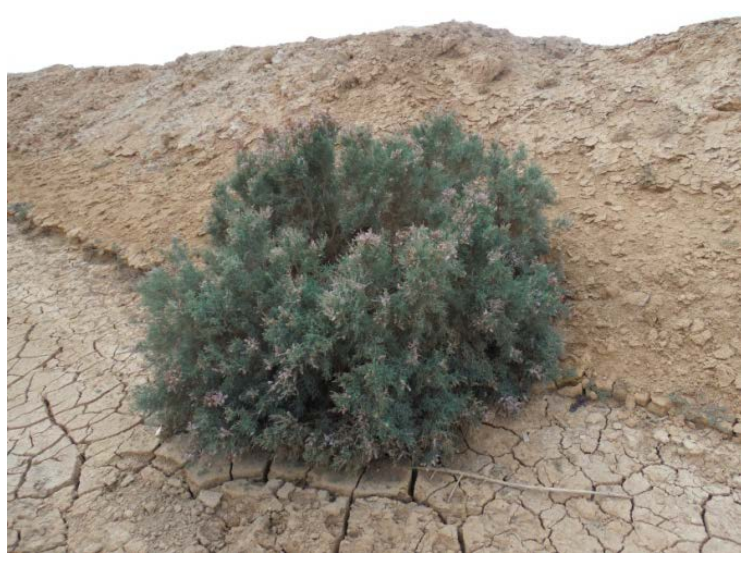

(b)

Figure 3. Tamarix jordanis, (a) Zarqa River, 2012; (b) Reaumuria, Azraq, 2014.

Tamarix can spread both in vegetative mode, by roots or submerged stems, and sexually, by seeds. Each flower can produce thousands of tiny (1 mm diameter) seeds that are contained in a small capsule. Seeds are usually attached to a tuft of hair that aids in wind dispersal, but seeds can also be dispersed by water.

A single mature salt cedar may produce hundreds of thousands of seeds between April and October. The tiny, hairy seeds can be widely dispersed by wind and water throughout the growing season. When they arrive at a moist spot they will germinate within 24 hours of moistening.

Tamarisks are evergreen plants growing to 1 - $18 \mathrm{~m}$ in height. Their slender branches have grey-green foliage, with scale-like leaves that overlap each other along the stem. The leaves may be encrusted with salt secretions since they own salt secreting glands. Tamarix living on salty ground accumulates the salt from the deep ground water in its foliage and when leaves fall of they increase the salinity of the surface soil. Tamarix can thus limit competition from other plants by taking up salt from deep ground water, accumulating it in their foliage, and from there depositing it in the surface soil where it builds up concentrations temporarily detrimental to some other plants until the salt may be washed away by heavy rains. The pink to white flowers form on $5-10 \mathrm{~cm}$ long spikes at branch tips. They often grow on saline soils, tolerating up to 15,000 ppm soluble salt and can also tolerate alkali conditions and may grow under quite adverse conditions as next to treated waste water course and desaliniation brines.

Tamarix species can survive fires, and has long tap roots that allow them to intercept water that is relatively deep in the ground.

Tamarix passerinoides has leaves like short scales (Zohary 1972, pl. 527 [11]) and prefers salty soil. Tamarix tetragyna is present everywhere else on salty and not salty soil with short spine like leaves (Zohary $1972 \mathrm{pl}$. 524-525 [11]). The bark of young branches is smooth and reddish-brown. As the plants age, the bark becomes bluish-purple, ridged and furrowed. The pink to white flowers form on $5-10 \mathrm{~cm}$ long spikes at branch tips from March to September, though some species tend to flower during the winter.

Tamarix was found to overlap in habitat type with Acacia in the hot dry area as was studied by Sher et al. (2010) [12]. They sought to identify patterns of water use by Acacia raddiana and Tamarix nilotica and found that Tamarix appears to be more dependent on groundwater than Acacia. Acacia species primarily use surface water during winter times and Tamarix species use groundwater from aquifers throughout the year. They thus concluded that Tamarix is unlikely to be a threat to the increasingly rare Acacia, even where the potentially invasive species may be flourishing. This can be supported by the occurrence of Tamarix in Jordan, where it grows only close to running or standing water.

Eshel et al. (2010) [13] mentioned the rapid growth of Tamarix trees under extreme desert conditions but with sufficient irrigation with waste water. Such production is in desert areas on non-arable soils and under extremely hot, dry and saline conditions. Reclaimed sewage and brines of desalination plants can be used for irrigating such trees that are naturally adapted to saline conditions. Tamarix trees also have a high capacity for regeneration after harvesting the above-ground biomass and need no repeated planting. Salt extraction by roots and its secretion from the leaves, through special salt glands decreases the danger of long term salt accumulation within the rooting zone. 


\section{Flora Connected to Karama Dam Reservoir}

Among the localities in Jordan which plants were found to grow on salty ground is the Jordan Valley where a distinct character and thus a unique assemblage of plants. Here plants grow in the surrounding of Karama Reservoire lake that contains salty water. The salt in that lake is of local origin, stemming from salt deposits underlying the dam reservoir. This salt has basically the same composition as the salt that is dissolved in the water of the Dead Sea. The salty ground water flows to the surface and collects in the dam lake [14].

Salicornia europaea (glassworth) of the Chenopodiaceae occurs near brackish water on sabkhas, salt marches, as for example at the margins of Karama salt lake (Figure 4(a)). As noted by Zohary (1966 pl. 227) [15] Salicornia grows on marshes in the Dead Sea area. Leaves and stems of Salicornia store surplus salt and have often acquired sausage-like shape. Therefore, in this annual plant the salt concentration is increased as a whole as expressed also by the color of the plant that changes from green to brown or red within the growth period, documenting at the end a near lethalsalt concentration [16].

The fresh green leaves can be eaten and taste only a little salty since they have not stored much salt at that stage of growth. The salt concenration increases within the growth period. The community formed by Salicornia can include Phragmites in brackish ceeks, on drier ground it joins Tamarix and also Suaeda may grow next to it. Closer to Lake Karama, were the ground becomes saltier Salicornia is replaced by Suaeda and Mesembryanthemum. The creek with Salicornia growing along its margin contains below the water surface Ruppia. On its margin Spergularia, Phragmites and Salicornia also surround the small pool in which a brackish spring issues from the ground. Salicornia can form a kind of reed around salty water bodies, where it can be accompanied by Tamarix on less salty beeches and by Arthrocnemum on saltier dry places (Figure 4(b)).

Salicornia is usually less than $30 \mathrm{~cm}$ tall, represents a succulent herb with a jointed horizontal main stem and erect lateral branches. Salicornia, in general appearance consists of predominantly stems with only minute leaves. Its color is glossy green and may change to yellowish-green or reddish in autumn. Leaves are very small, of simple cylindrical shape, fleshy, attached opposite to each other on each node, but the young Salicornia plant appears leafless.

The flowers are without stalks (spiked). The hermaphrodite flowers are wind pollinated, and the fruit is small and succulent and contains a single seed. Flowering time is August to October.

Salicornia species can generally tolerate immersion in salt water. Salicornia europaea is a highly resistant salt plant that, according to Aronson (1989) [1] tolerates salinity above that of sea water and it has the potential to extract salt from the soil (phyto-remediation). Zohary (1966 pl. 227) [15] noted that it is one of the leading plants, occupying drying up salinal puddles. This species is one of the most common halophyte found around the world.

Salicornia can be eaten and it tasts salty. The plant occurs near water with a salinity that ranges from 15,000 to $21,000 \mu \mathrm{S} / \mathrm{cm}$. When salinity rises higher, as was the case in the lake of Karama in spring and fall of 2012, the plant was eliminated. Salicornia is associated with the submerged Ruppia in water with a pH value of about 8.00 .

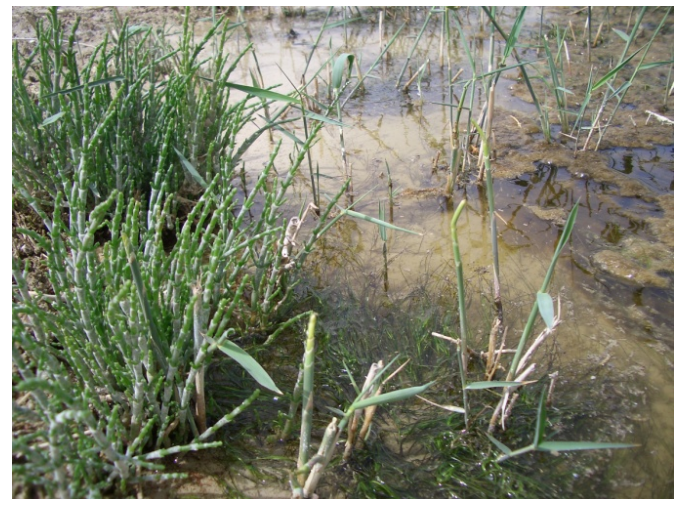

(a)

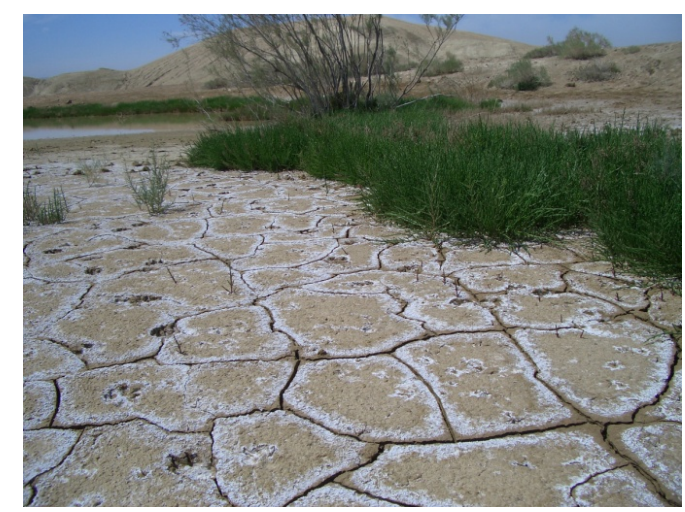

(b)

Figure 4. (a) Salicornia, Ruppia and Phragmites in a creek with brackish water near Karama revervoir Karama, 2012; (b) Salicornia forming a belt at the margin of a salty pond with a Tamarix and with Arthrocnemum in the back (2013). 
Suaeda grows next to and usually above Mesembryanthemum along the shore of Karama Reservoir (Figure 5(a)). The species belonging to Suaeda along the shore of the Karama Reservoir resemble Suaeda vermiculata or Suaeda aegyptiaca in Zohary (1966, pl. 231 and 235) [15], but more species of Suaeda have been determined to occur near the Dead Sea on saline ground (Zohary 1966, pl. 229-233 [15]). Species of Suaeda are best distinguished by the position of their flowers, which during most of their growth time can not be seen. Thus the most common Suaeda vermiculata belongs to a taxonomically complicated complex of several closely related subspecies or species of Suaeda as they occur in Jordan and neighboring countries.

The fleshy, cylindrical leaves are much longer than among other Jordanian halophytes such as those of the genera Salsola which are usually found on dryer ground and Salicornia growing on moister ground. The young plant is fleshy, green with the subsequent foliage usually densely covered with minute hairs. Stems are slender and ascending to erect with woody base and branched throughout. Leaves alternate and are 3 - $9 \mathrm{~mm}$ long, ovate with rounded tips. The flowers come in summer and are solitary (rarely 2 or 3 ) in leaf axils at stem tips. Its leaves are often pinkish and small. Seeds are rounded and slightly flattened with a transparent membranous seed-coat (pericarp). The succulent plant concentrates the surplus salt in special cells in the leaves, as in the case of chlorid-halophytes.

Meadows of Mesembryanthemum grow on the muddy bottoms of flats near the lake, further up tickets of Suaeda grow, along creeks even further up Salicornia is dominant, and on the hills above former lake levels Tamarix is found. At the edge of creeks Tamarix as well as Phragmites grow in the area with less salty water.

Mesembryanthemum nodiflorum of the family Aizoaceae, subfamily Mesembryanthoideae was documented by Zohary (1966 pls 93-94) [15] and Al-Eisawi (1998) [17] to grow near to the Dead Sea. The short plant covers the stony as well as the sandy and fine grained ground on the exposed region closest to the salty reservoir of Karama Lake (Figure 5(b)). It can also be found to grow on quite dry and salty ground in saltier places than those covered with Salicornia, and also with Suaeda.

This succulent plant is a chlorid-halophyte which concentrates the salt in special cells. The plant lies close to the ground and forms rosettes. Leaves and stems thus have a blown-up shape, often sausage-like and with the cells having glassy color. The plant grows close to the ground and forms rosettes of fleshy papillose leaves. The leaves are thick cylindrical, up to $2 \mathrm{~cm}$ long, and visibly bumpy with shiny, bubble-like papillae.

Its characteristic flowers have split petals and are arranged singly. Flowers are solitary or borne in loose clusters. Each is about half a centimeter wide, with many narrow to thread-like white or pale yellow petals. The fruit is a capsule which opens when it becomes wet, releasing seeds. The flowers are closed in the morning and open later on.

Stress produced by salt can also be overcome by reduced evaporation during photosynthesis. This reduction allows life with less water and thus less salt is introduced into the plant [16]. These authors report that, according to studies carried out with the growth of Mesembryanthemum nodiflorum compared with those of Suaeda maritima, the first is more sensible to higher concentrations of $\mathrm{NaCl}$ than the later. This does not well agree with the observation in the field in Jordan that Suaeda maritima is found in all four locations with salt tolerating

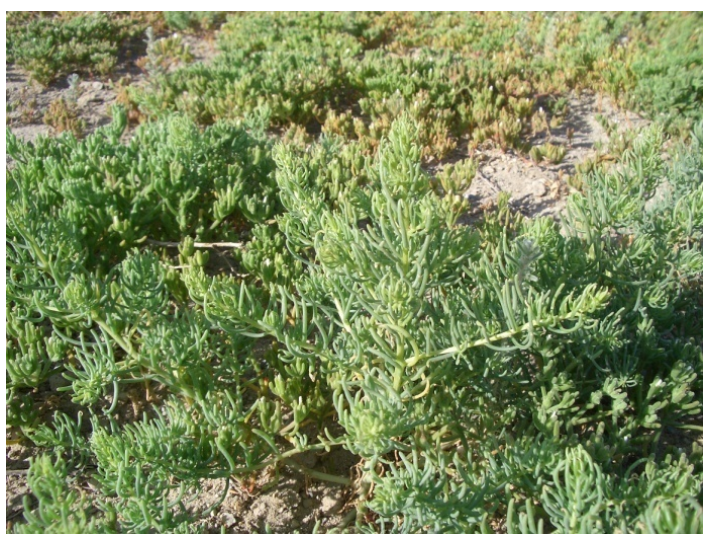

(a)

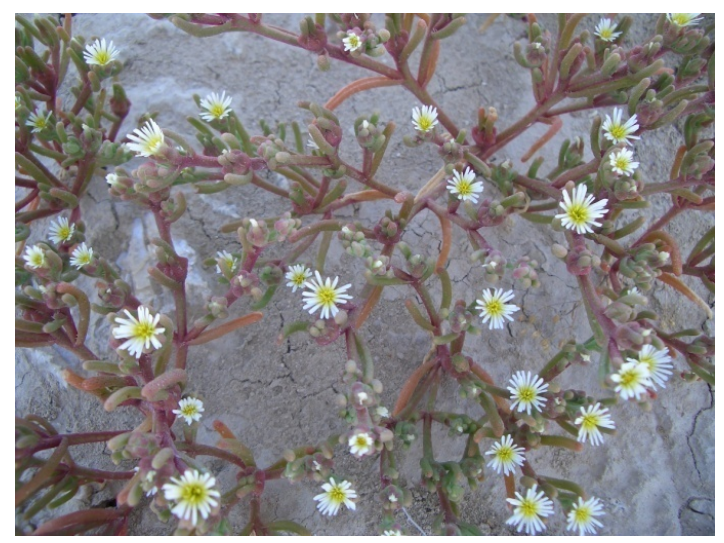

(b)

Figure 5. (a) Mix of Suaeda in front and Mesembrynthemum further down on the shore (Karama, March 2013); (b) Mesembryanthemum with its flowers, upper and lower reaches of Karama 2013. 
flora and where Mesembyanthemum was noted to occur only near Karama Lake, and not in Azraq. Mesembryanthemum opens its flowers only around noon, thus the flats covered by it near Karama Lake look quite different in the morning than in the afternoon.

It grows on fine grained salty ground flooded at spring time, and becomes dry when flowering occurs as observed in the upper small part of Karama Lake (spring 2013), and also downstream of Karama dam near pools of water seepages.

Ruppia maritima, wigeongrass, grows in a brackish creek that flows from a spring to the Karama reservoir, and it forms dense thickets in the creek that leavs Lake Karama towards River Jordan (Figure 6(a)). It is a thread-thin, grass-like annual or perennial herb which grows from a rhizome anchored shallowly in the wet substrate. It develops a flowering point tipped with tiny flowers which usually extends above water. The seeds can spread by water and can be transported inside the guts of fish and waterbirds which eat the fruits. The plant also reproduces by sprouting from its rhizome to form new colonies. Ruppia maritima has a wide salinity tolerance but was not seen in fresh water in Jordan, only at places with brackish water, here also in shallow pools next to Karama Lake, but not in the Lake itself. Spergularia was noticed to grow during spring-time at the small brackish creek next to Salicornia and Ruppia at Karama (Figure 6(b)). Its flowers are small and inconspicuous.

Phragmites australis is a tall, perennial wetland grass that grows in temperate and some tropical regions and is one of the most widely distributed flowering plants on Earth. Feinbrun Dothan (1986 pl. 353) [18] reported it as common reed from the banks of rivers and lakes in Jordan. Phragmites occurs in fence-like growth along waterways such as brackish and freshwater marshlands. It is found also around hot springs, as in Zarqa Ma'in, or in alkali springs as in Maqarin.

The plant is large, perennial, clonal and often has dense, nearly monospecific stands. It has hollow stalks with $2.5 \mathrm{~cm}$ in diameter and standing from 2 to $4 \mathrm{~m}$ tall. The leaves are stiff, smooth, alternate, entire and lanceolate shaped. At the end of the stalk, in fall time, a bushy flowering panicle with purplish to tan, later silver, fluffy appearance grows with hairy seeds.

Phragmites australis develops an extensive subterranean network of rhizomes and roots. It also grows vegetative through horizontal growth of the rhizomes. Nutrients are stored in the roots from which new plants can grow. This grass tolerates salt to some degree, as around the ponds of Azraq and along the brackish creeks at Karama, but is not present in the growth zone of Mesembrynathemum in Karama Lake beach or of the Spergularia growth belt on the eastern Azraq Sabkha.

Fresh to brackish marshes have extensive Phragmites reed-beds around the margins of the lake, and a large area of brackish Salicornia flats with scattered clumps of Phragmites and Tamarix on the plains.

Arthrocnemum macrostachyum represents a halophyte which flowers in summer. It is a much branched shrub that lives on saline ground near the Dead Sea along the lower Jordan Valley (Zohary 1966, pl. 226 [15]; AlEisawi 1998, Figure 96 [17]). Leaves are scale like and the thick stem is green, jointed and fleshy when young, becoming later in life woody and not jointed. Flowers appear in a transverse row at the end of some stems and

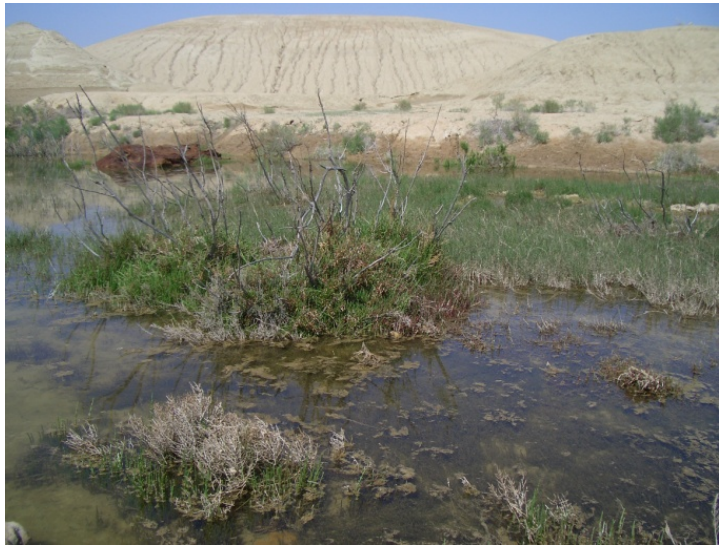

(a)

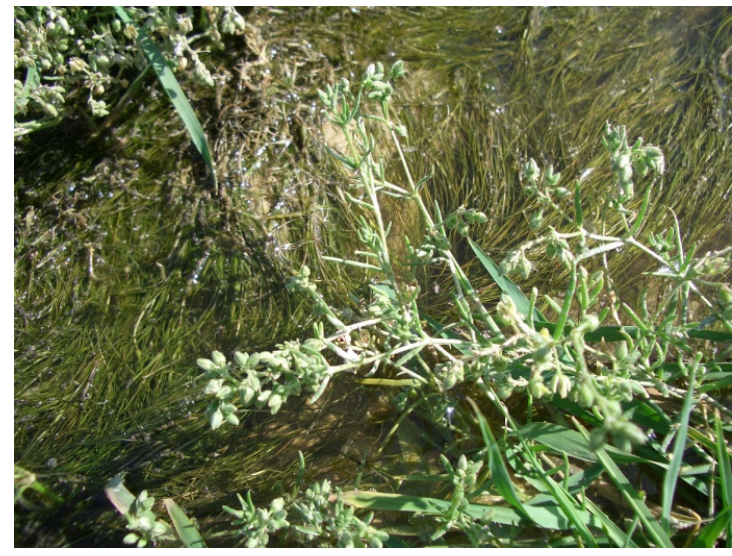

(b)

Figure 6. (a). The creek that leaves Karama Reservoir has a densed population of Ruppia below water and Arthrocnemum and Tamarix bushes growing on its shore. The hills behind have been pushed up by diapiric salt; (b) A small creek at Karama (2013) with Ruppia and Spergularia media, and next to it Phragmites. 
are more or less radially symmetrical. The fruits have brown membrane like sides and the seeds are quite tolerant to salty environment. Albert (1982) [4] noted that the roots contain large amounts of woody tissues, both vessels and lignified parenchyma. The root cortex showed air spaces which help in anaerobic growth conditions in which the plants are growing during part of their life-cycle. The leaves contain an assimilatory palisade layer and a water storage tissue connected with the epidermis by a number of vessels which play a role in the uptake of dew by the stomata.

The species was characterized by Al-Eisawi (1998) [17] as salt loving plant found in Jordan salt flats. It grows along the creek that runs from Karama reservoir to the Jordan River as noticed during the spring of 2013 (Figure 7(a)). Here it can be considered as a plant tolerating very salty water, with Ruppia next to it in the water.

In the salty environment below the Karama Lake and near to the creek that leaves it towards the Jordan River Arthrocnemum macrostachyum is growing. This green prickely bush is characteristic for salt loving plant communities found on Jordanian salt flats (Zohary 1966, pl. 226) [15]. Arthrocnemum macrostachyum is accompanied by Salicornia europaea as yearly herb on the margins of salty ponds and creeks.

Atriplex of the Chenopodioideae and the family Amaranthaceae is also called saltbush or orach. The plant has a fine film of hairs on its leaves and thus appears to be of gray color. Atriplex has been used as food plant in prehistoric times and in the Roman Period also in Middle Europe. The genus is quite variable and widely distributed. Atriplex includes many desert plants as well as halophytes and it also growing in moist environments. The name saltbush derives from the fact that the plants retain salt in their leaves. This makes them useful in areas affected by soil salination due to its removal by harvesting the plant. As soon as the hairs which cover the leaves are filled with salt they may detach by a preformed brake off, either by its own, or when hit by rain drops [16]. Atriplex can thus store salt in vacuoles and excretes it to the leaf surface through the special salt glands. When much salt is concentrated in them they can be shed thus easing the load of salt. The flat, slightly fleshy leaf blades are either entire, serrate, or lobed and very variable in shape. The inflorescense is a cluster of flowers and the flattened seed is thick and leathery.

The genus Atriplex is distributed nearly worldwide. Atriplex halimus and Atriplex leucoclada occur in the Jordan Valley (Zohary 1966, pl. 204-208) [15]. Atriplex halimus lives near saline meadows and marsh edges, as was noticed near the Karama flood plain, here together with Prosopis in the same position (Figure 7(b)). Saliniation of soil occurs also due to irrigation and subsequent evaporation in the Jordan Valley and here Atriplex halimus, Prosopis farcta, Tamarix also find fitting conditions for growth.

Beta of the family Amaranthaceae together with Beta vulgaris was noticed with few individuals on the formerly flooded flat of Karama Lake together with Limonium. Beta vulgaris is known to tolerate some salinity in the ground. Beta vulgaris is best known in its numerous cultivated varieties known as the beet-root or garden beet. Beta vulgaris subsp. maritima, commonly known as the sea beet, is the wild ancestor of these, and is found throughout the Mediterranean shores, the Atlantic coast of Europe and the Near East. Beta vulgaris has heartshaped leaves arranged to form a rosette on the base of the plant and the flowers are in dense clusters, each one,

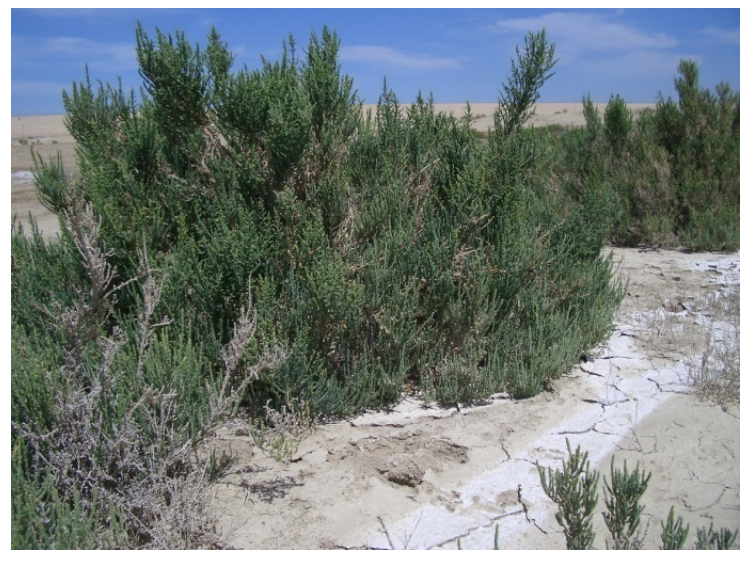

(a)

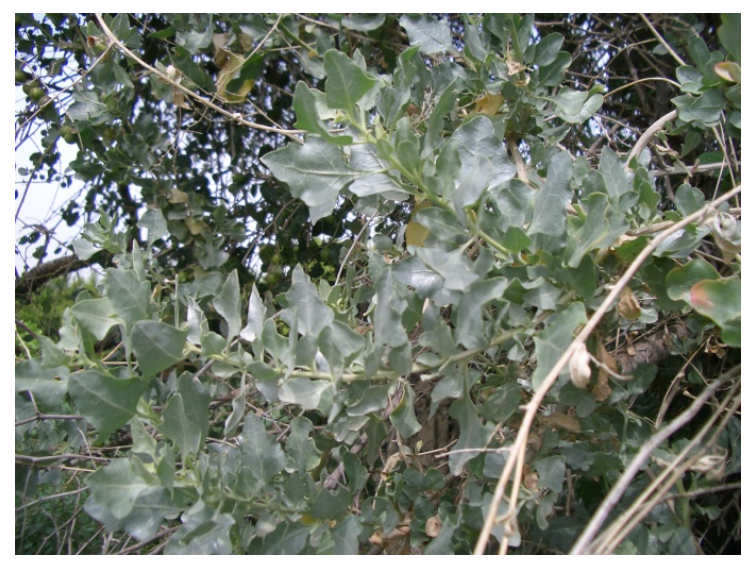

(b)

Figure 7. (a) Arthrocnemum macrostachyum downstream of Karama dam 2013; (b) Atriplex halimus, Karama, 2012. 
3 - $5 \mathrm{~mm}$ is diameter, green or tinged reddish, with five petals. Flowers are wind pollinated. Beta vulgaris is a weed in agricultural fields as those near the Karama Reservoir as well a near Amman where it was found to flower by the end of March 2013.

These mud flats with salty groundwater have also Pteranthus dichtotomus (Zohary 1966, pl. 195 [15]) which is not an indicator species for saline environment, but can tolerate it and grow on it. It is more commonly between rocks in the Zarqa Valley.

Limonium lobatum, sea-lavender, grows more than $10 \mathrm{~cm}$ tall from a rhizome. This opportunistic halophyte lives on salty soil of the northern flats which are periodically inundated by the salty Karama Lake (Figure 8(a)). From a basal rosette of wavy, lobed leaves rise broadly winged stems with one sided clusters of purple and white, papery flowers. Its leaves have glands which excrete salts from the tissue of the plant. This excretion moves the salts out of the plant onto the surface of the leaves where they crystallize and could be washed away by rain or dew. The small fruits are retained in the papery calyx and have one seed each. Limonium tolerates moderately salty soil and was found next to Mesembryanthemum on the salty flat of Karama that were flooded in winter 2013. On that same flat in spring 2014 no plant was encountered. Limonium also grows in environments which are not salty, and found flowering on the slopes of the Zarqa River near King Talal Lake on dry soils eroded by rain water in spring 2014.

Asteriscus pygmaeus grows among salt loving plants such as Mesembryophyllum on the fine grained soils of the flats surrounding Karama Lake and at the margin of King Abdalla Canal near Al Qarn (Figure 8(b)). Asteriscus pygmaeus has a rosette of leaves with soft hairy surface and a yellow flower on a short stalk, one of which may have ripe seeds, while the others next to it are just budding. The plant prefers dry ground and is encountered on salty ground, but not restricted to it (Al-Eisawi 1998, Figure 139 [17]). The seeds are connected to a wooly pappus and can be spread by wind. Feinbrun-Dothan (1978 pls. 538, 539) [19] documented the main differences between the short Asteriscus pygmaeus and the higher branched Asteriscus graveolens that grows on non salty ground in dry river beds.

Closer to the non salty area next to Karama Lake the spiny bush Prosopis farcta is encountered which according to Zohary (1972) [11] is a component of the saline and riparian vegetation in the Dead Sea area and along the banks of the Jordan River. Prosopis in Jordan also grows on soils without salt as is the case near the creeks outlets to the Jordan Valley and along the lower reaches of Zarqa River. Prosopis farcta can concentrate salt as part of its roots. At Karama it was found only in maginal position of the periodically inundated salty flats and here jointly with Atriplex halimus (Figure 9(a)). The presence of both species here documents only slightly raised salinity probably only periodically and fresh water conditions during most of the time.

Capparis spinosa prefers dry heat and intense sunlight (Zohary 1966, pl. 358 [15]). Capers are salt-tolerant, and the plant consists of creeping branches of up to $3 \mathrm{~m}$ long. Leaves have elliptical shape and long duration on the plant. The plant bears curving thorns and its flowers are large and solitary with numerous and long stamens. Capparis was found to grow next to Karama dam on stones (Figure 9(b)). Capparis spinosa has been studied by

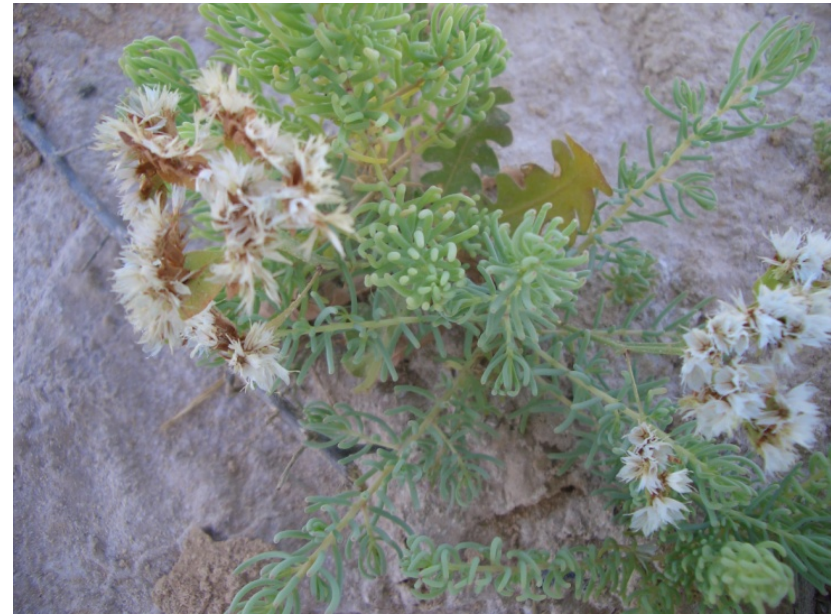

(a)

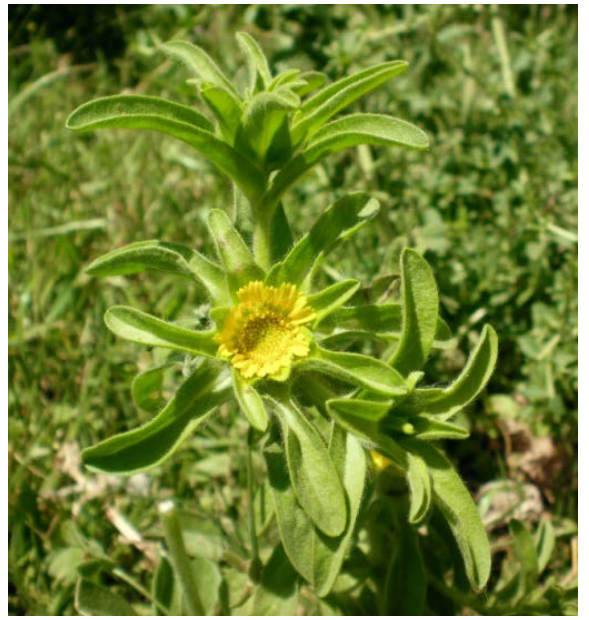

(b)

Figure 8. (a) Limonium together with Suaeda from the flats of Karama Dam, 2013; (b) Asteriscus pygmaeus, Karama 2012. 


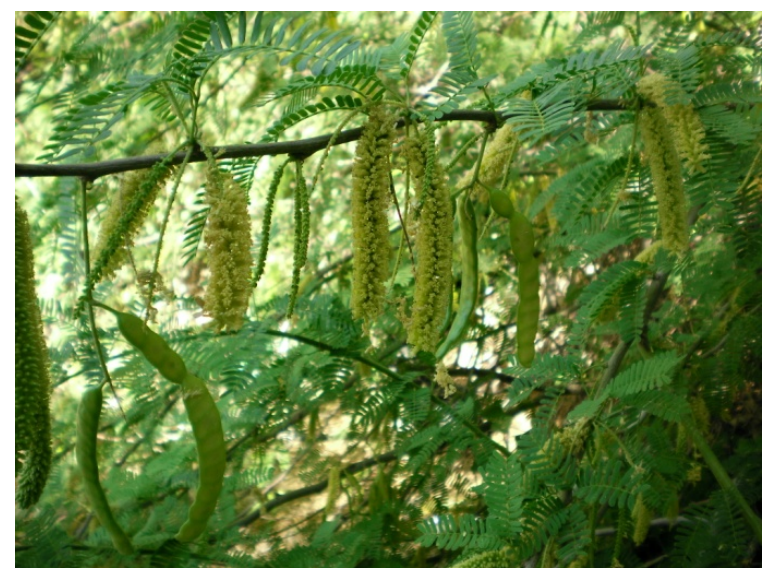

(a)

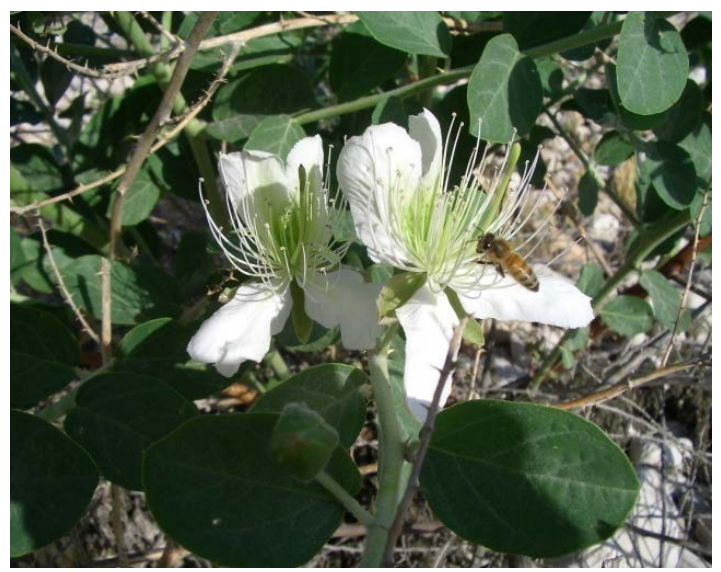

(b)

Figure 9. (a) Flowering branches and fruits of Prosopis farcta from the margins of Karama dam 2012; (b) Capparis spinosa from Karama area 2014.

Aronson (1989) [1] who noticed that it represents a salt tolerant shrub. Its occurrence on the rocks of the dam confirms that. It is also growing from stone walls in the surrounding of a Citrus plantation in the Jordan Valley and from rocks surrounding Kafrein reservoir, is thus tolerate some salt but is not restricted to growth on salty ground.

Cressa is a genus of the Convolvaceae which are known generally as alkali-weeds. They are clumpy and lowgrowing but usually have erect stems covered with white-haired, green leaves. They produce tiny white to pink flowers about half a centimeter across. Cressa cretica was encountered in the lower Wadi Shita near the creek in non salty environment, as well as on the margin of the salty Sabkha; Taba in Wadi Araba (Figure 10(a)). It forms low bushes of only around $30 \mathrm{~cm}$ high with minute leaves which can be covered by salt, but in the encountered locality they were normal smooth green. The root stock is woody and perennial. The small flowers are close together in the cylindrical end of the stem and have pink color. Fruits are capsular. Cressa cretica is salt resistant [17], but was noted to grow commonly also in cultivated fields. Feinbrun-Dothan (1978 pl. 46) [19] suggested that it grows on somewhat saline soil as repeated by Al-Eisawi (1998 Figure 233) [17].

Albert et al. (2004) [16] also noticed that Halopeplis amplexicaulis and Cressa cretica grow in the Jordan Valley area each year after the area had fallen dry in summer. Halocnemum strobilaceum was present here and the open salt-meadows have also the grass Aeluropus littoralis growing. They noticed Tamarix passerinoides and Nitraria retusa growths and Juncus maritimus arabicus and Phragmites australis forming belts of reeds, and on drier ground growth of Salsola tetrandra and Suaeda fruticosa.

Aeluropus littoralis as grass of the Poaceae can live on salty ground, has alternate leaves on its stem and grows from an elongated rhizome. Its central stem is $5-30 \mathrm{~cm}$ long and leaves are branching with the leafsheaths longer than adjacent internode of the stem. The flower stand is $1-4 \mathrm{~cm}$ long with crowded flower in two rows. The grass secretes salt through its roots.

Brackish and saline grounds have the small size Aeluropus, as well as the high grass Phragmites australis (Figure 10(b)). Aeluropus littoralis was noted by Albert et al. (2004) [16] to secrete fluid with concentrated sodium salt. Neither Aerulopus nor Phragmites are growing on the salty flats in the NE of the Azraq plain, but they are present with the flora that surrounds the ponds on its western edge.

\section{Azraq Basin and Its Sabkha}

Azraq Basin represents a member of a chain of ancient lakes that stretched from northwestern Saudi Arabia to northeastern Syria during the wetter times of Pleistocene. During times at which ice covered much of northern Europe the climate in Jordan was considerably wetter than today and the open plains between shallow lakes were ideal for hunting. Animals such as elephants, rhinos and horses were hunted by early men when they came for drinking. The lake at Azraq during the Pleistocene pluvial period covered up to $600 \mathrm{Km}^{2}$ [20], with a zone of reeds on its margin and trees near the shore. The lake had little currents and thus fine grained and organic sediments were deposited in its central part. Only near the mouths of wadis entering the lake in the east, west and 


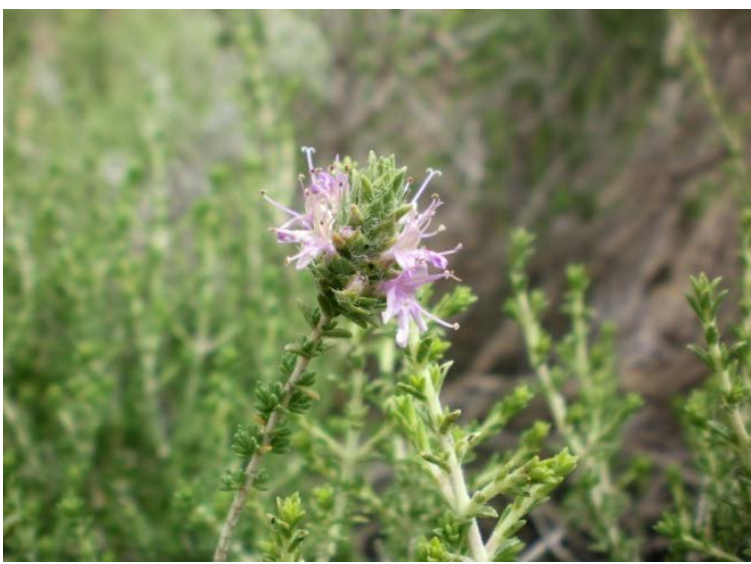

(a)

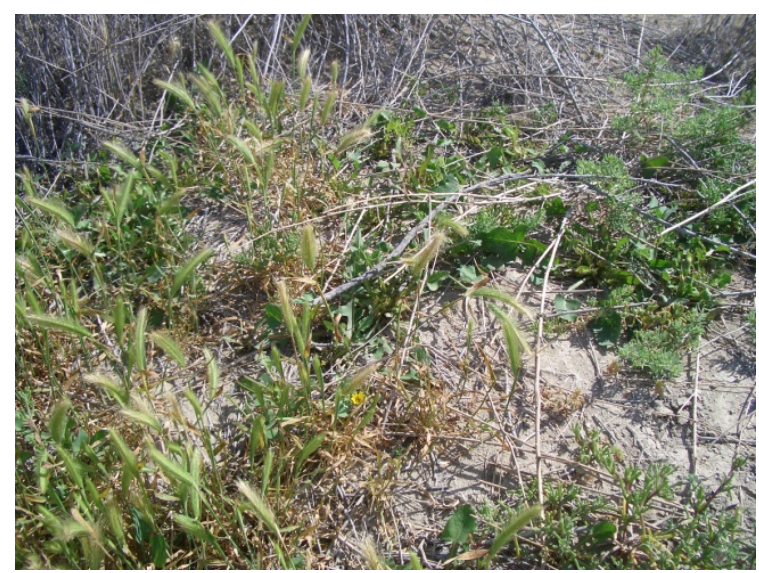

(b)

Figure 10. (a) Cressa cretica from the Jordan Valley 2013; (b) Grasses near the salt flats of Karama.

south coarser sediment were washed into the lake and formed fans, documenting that its shores were of low relief. Further to the west of the Azraq basin a wedge of debris had been washed from the large volcanic fields extending from Jebel Druz to the southeast. Here volcanic activity had resulted in the production of much new rock material that during rainy periods allowed large fan of reworked volcanic rock to form. It finally separated the Azraq Lake from its former outflow to the west that existed along Wadi Dhuleil to River Zarqa at the time when Lisan Lake filled much of the former Jordan Valley. Also the flow of water towards Wadi Sirhan further to the south and east was hindered by low ridges of debris between the individual basins [21].

The salty moist flats in the North-Eastern part of Azraq have their own character. Here water is basically derived from the extensive hilly area, which further to the North joins the mountainous area of Jebel Druz built of volcanic rocks. Water issuing from the NE margin of the Azraq flat consists, for most of the time, of ground water that has moved for a long distance through the volcanic aquifers. It emerges at their margin that forms the edge of the Azraq basin in the North and Northeast, where evaporates were deposited. When rains were added during the moist period of the year the salt dissolved and a shallow brackish lake formed, which relatively rapidly evaporated again. Its margins have water with little salt, while when shrinking the water turns saltier. Along the shore of that short-lived lake flora develop, while further from the shore no higher plant were able to grow. When dried out mud cracked formed.

On the north-eastern side of the large mostly barren Azraq sabkha a thin veneer of plants is found next to sparse growths of Tamarix bushes. Here a rim of low plants has grown at the margin of a shallow lake that had formed after some rains, but was dry when we visited the place leaving a mud cracked plane that only rarely exposed still moist surface area. This rim is the place of growth of two small sized species belonging to Spergularia. One in the more landward upper part formed by Spergularia cf marina which has narrow thick green leaves (Figure 11(a)), and the other composed of more rounded leaves is Spergularia cf media, which in more salty growth environment has many leaves transformed into salt stores, tinged red (Figure 11(b)).

Spergularia marina and Spergularia media occur on salty ground (Zohary 1966, pl. 171, 172 [15]). Here on the former margin of the shallow short-lived lake they form a very distinct rim with Spergularia marina at the upper-landward margin and Spergularia media right next to it, closer to the former lake. Spergularia marina has a flower diameter of about $6-8 \mathrm{~mm}$. The narrow stem is lined with green fleshy linear leaves. The flowers have five pointed short and green sepals and five oval white or pink-tinged petals. The tiny seeds have winged margins. The sprawling annual plant may survive in its roots and is salt loving.

Spergularia cf. marina lives close to Spergularia cf. media which is rather similar to it. The leaves are fleshy and of semi-cylindrical shape. And they grow next to juvenile Suaeda. Spergularia cf marina grows on the upper rim that reflects the highest stand of the lake when it was filled and the other just a little below is composed of Spergularia cf media with grey and smaller leaves. Its growth zone reflects the position of the beach of the lake when it had evaporated so much that water level laid a few centimeters lower. Spergularia here develope purple globular leaves in which surplus salt is stored. Among individuals that have grown in former puddles, below the beach zone, Spergularia has even higher puplish storage leaves and their growths are commonly 


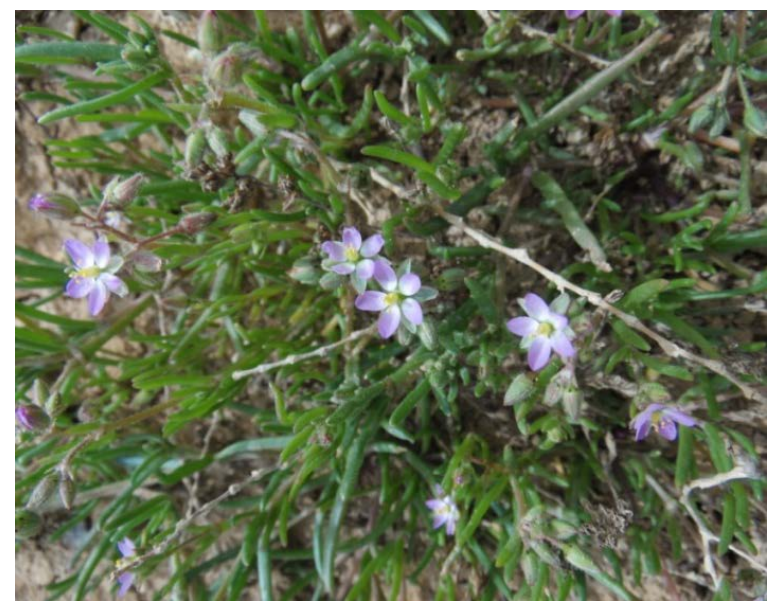

(a)

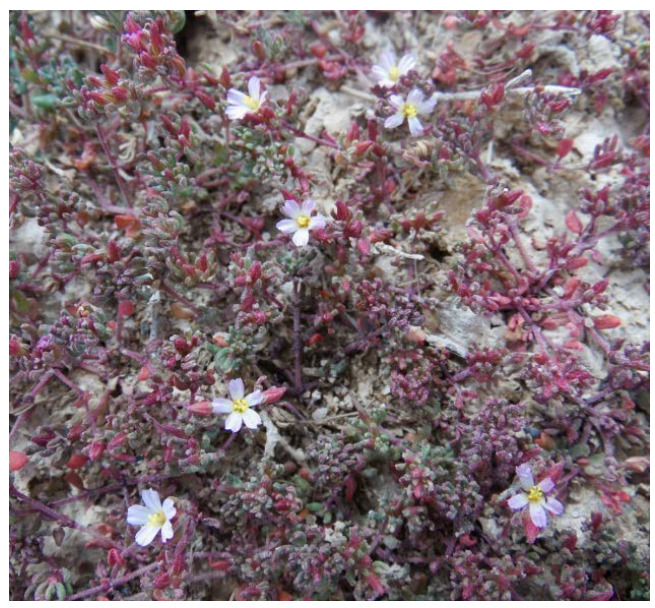

(b)

Figure 11. (a) Spergularia cf marina with elongate green leaves, Azraq, 2014; (b) Flowering Spergularia cf media with many red leaves for storing salt, Azraq Sabkha, 2014.

accompanied by juvenile Suaeda. Within the puddles obviously salt content of the water had increased even more during evaporation of the water. When the lake level decreases Spergularia stop growth while Suaeda continue even though the level of salinity is still rising. But further out, on the sabkha level, no plants grow any more, since the bottom contains to much salt.

Aaronsohnia grows in hot environment on dry river beds and on salty ground (Figure 12(a)). Achillea on field margins and also among halyphytes. Aaronsohnia with only one species in Jordan according to Feinbrun-Dothan (1978, pl.585) [19] grows in the desert, as is the very simlar Matricaria aurea that represents a very similar composite plant and forms dense growths along the nitrate rich water of Zarqa River. Aaronsohnia resembles Anthemis regarding the finely lobed leaves and differs by having no white marginal leaves on its composite flower stand.

Anthemis and Aaronsohnia as well as Crepis grow singly within the growth zone of Spergularia on the margin of the NE Azraq Sabkha (Figure 12(b)). In Anthemis leaves are lobed and disected into narrow elements and the composite flower has yellow disc and white leaves surrounding it. In Jordan 4 species of Anthemis are described by Al-Eisawi (1998, Figure 130) [17] and Anthemis haussknechtii was noticed to grow in Azraq as documented by Feinbrun-Dothan (1978) [19].

Crepis sancta that closely resembles Crepis biennis was found on salty ground in Azraq (Figure 13(a)) and was noticed on similar salty ground near the beach at Aqaba 2014. According to Feinbrun-Dothan (1978, pl.753) [19] the plants may grow $20 \mathrm{~cm}$ high, are annual with a stem rising from a rosette of elongate and dentate leaves with hairs. The stem is forked above the middle with yellow flowers, one at the end of each branch. Fruits are connected to a pappus and can fly off with the wind. The plant grows in the desert and also on salty ground. Al-Eisawi (1998, Figure161) [17] noticed the plant to grow especially next to roads all over the country but also in the hot regions of the Jordan Valley. Feinbrun-Dothan (1978) [19] and Al-Eisawi (1998) [17] did not indicate that Crepis sancta can grow successfully on salty ground. Each of the three composites represents facultative inhabitants on salty ground.

Neotorularia torulosa is a cruciferan with a characteristic growth. The first which forms rosette of narrow elongate leaves has a small group of white flowers in its center. In case growth continues, long side shoots develop which have numerous centers of flowers. This further growth is dependent on the availability of water. Thus with plants in drier surrounding only a central group of flowers is present, while those growing in more humid surrounding have long flowering side branches. The plant was found growing on the muddy ground of Azraq dry lake after flooding and drying (Figure 13(b)). It tolerates salty water to some degree. Its locality of growth appears to be in an area less affected by salt as is the case with Spergularia. It is determined as Torularia torulosa according to Al-Eisawi (1998, Figure 269) [17] and grows in marginal desert habitats, obviously also when the ground is salty.

Trigonella stellatum also grows on the salty ground of the northern mud flat of Karama reservoir and clearly tolerates some salinity. This small plant can also be found on salty ground with clay and sand in the Azraq flat 


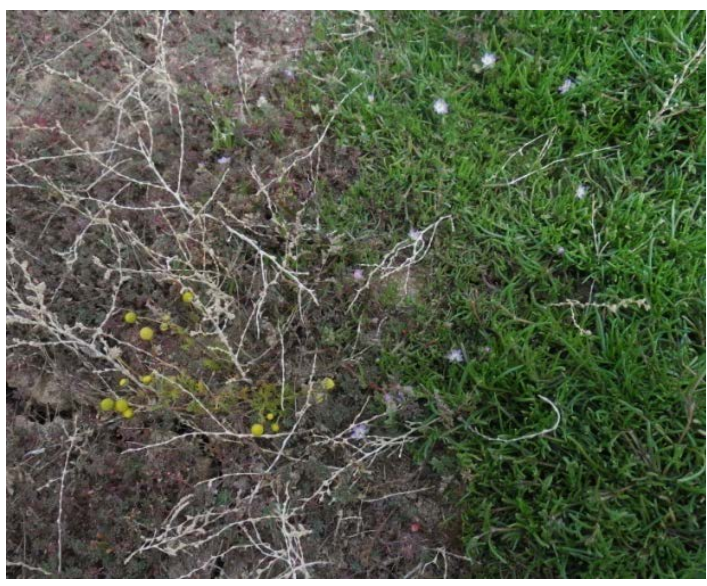

(a)

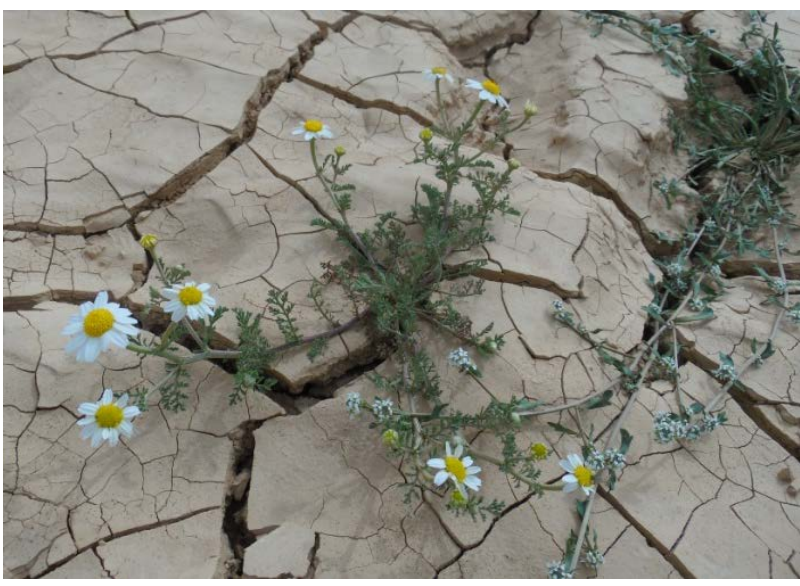

(b)

Figure 12. (a) Azraq Sabkha floor with Aaronsohnia next to Spergularia cf marina; (b) Anthemis together with Neotorularia on the mud cracked surface of the moderately salty Azraq Sabkha 2014.

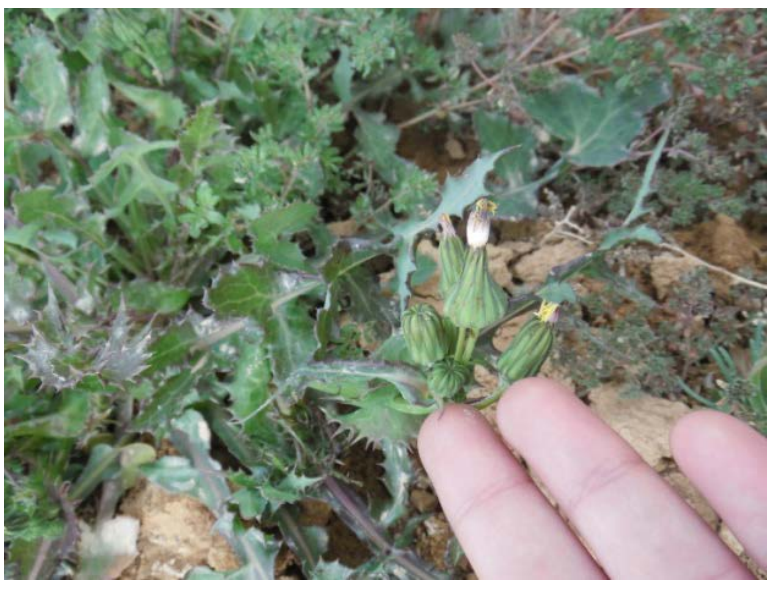

(a)

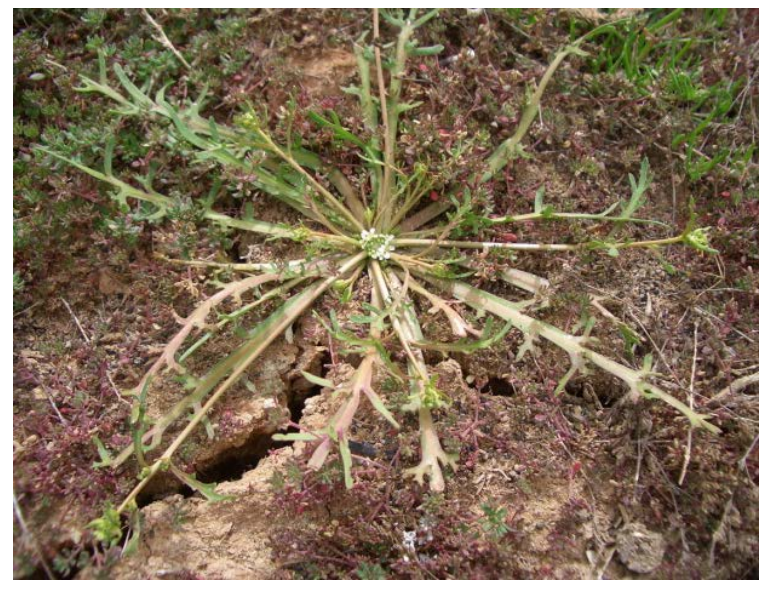

(b)

Figure 13. (a) Among the Spergularia, Crepis occurs rarely in Azraq; (b) Neotorularia from Azraq Sabkha (2014) as influenced by relatively weak salinity. Neotorularia together with the smaller Spergularia, Azraq 2014.

as well as on fine sand near Aqaba shore (Figure 14(a)). It is not restricted to salty ground but also grows on muddy grounds along river margins. Trigonella was noticed to grow among the Spergularia and young Suaeda.

Suaeda vera according to the descriptions of Al-Eisawi (1998) [17] and Zohary (1966 pl. 229) [15] represents a perennial or annual succulent herb that grows $20 \mathrm{~cm}$ high with dark green leaves which are arranged star-like on the part and having fleshy stem often with pink pigment (Figure 14(b)). The fleshy, cylindrical leaves are much longer than among other Jordanian halophytes such as the genera Salsola and Salicornia.

\section{Pond and Its Surrounding in the Western Azraq Sabkha}

Tamarix tetragyna with its short needle-like leaves (Zohary 1972 pl. 524-525 [11]) grows in a belt of bushes around the ponds at the western margin of Azraq flats. Here the ponds have been reconstructed near the ancient Roman and early Islamic constructions, after they had been totally dry some 20 years ago, which destroyed their original fauna while their flora has regenerated since. The ponds are now settled densely by the water plant $M y$ riophyllum and the reeds Phragmites and Juncus which grow next to it and along the canals connected to the pond.

Myriophyllum spicatum, milfoil, of the order Saxifragales and family Haloragaceae is a submersed aquatic plant with elongate stems that may reach several meters in length with air canals and whorled leaves which are finely-divided. The flowers are small and usually borne in leaf axils and grow to be held above the water surface. 


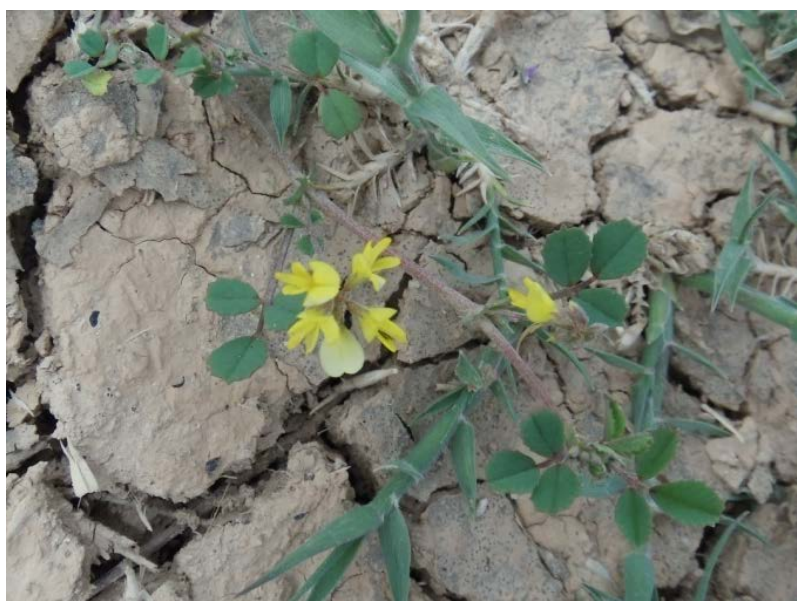

(a)

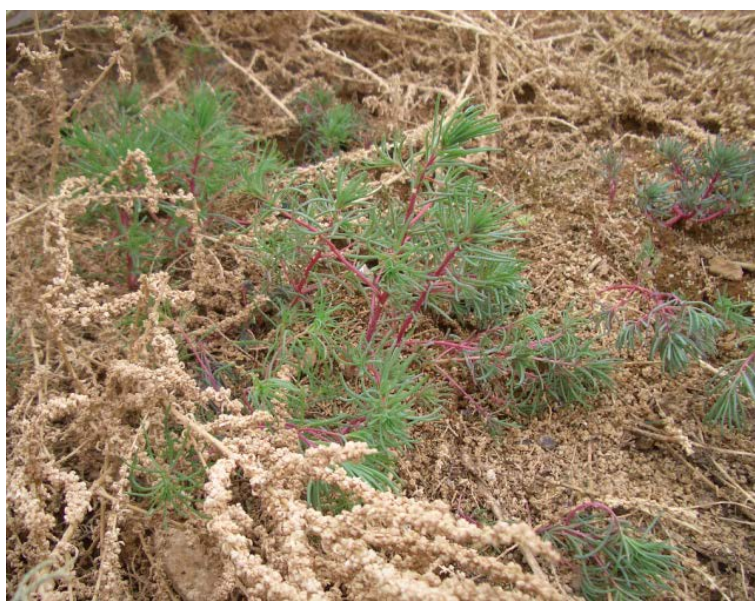

(b)

Figure 14. (a) Flowering Trigonella, Azraq 2014; (b). Suaeda vera from Azraq growing on high salinity ground, and just arising among Spergularia.

The fruit splits into four nutlets at maturity. The submerged leaves are approximately $2 \mathrm{~cm}$ long and arranged in pinnate whorls of four, with numerous thread-like leaflets. The Jordan River, before it became polluted included a rich diversity of submerged macrophytes which are currently totally absent there. The submerged macrophyte community included among others the milfoil (Myriophyllum spicatum) (Zohary 1972, pl. 549 [11]) which grows now in Azraq ponds (Figure 15(a)).

Juncus maritimus arabicus (=Juncus rigidus) as a rush differs from other grasses by the round smooth simple leaves. Juncus has nude leaves which contain spongy internal material. They bear the inflorescence near the tip. Juncus rigidus occurs also at salty springs, just like the larger Phragmites. The plant grows from its roots and lives for one or several years. The stems are rounded and the leaves are flattened. A tufted perennial herb Juncus maritimus has the inflorescences about $60 \mathrm{~cm}$ high with very acute leaf apices. It grows in salt marshes and salt water pools by oases similar to Juncus maritimus arabicus (Figure 15(b)), which is commonly found near springs in Jordan often together with Juncus acutus. Feinbrun Dothan (1986, pl. 186, 187) [18] noticed the mix of both species especially in saline soils. We found it to be common around the Azraq pool area.

Nitraria retusa is a salt-tolerant shrub or bush that grows to $2.5 \mathrm{~m}$ tall, although it is usually less than $1 \mathrm{~m}$ in height. It has tiny, white to green, fragrant flowers, and small edible red fruit. The plant is native to desert areas of North Africa, where it grows in primary succession on barren sand dunes. It naturally occurs in arid climate and is also native to North African deserts [22]. In Jordan Nitraria retusa was recognized by Al-Eisawi (1998, Figure 486) [17] as living in Azraq (Figure 16).

In Azarq area, from the moist but salty environment at the transition to the desert also Anabasis articulata, Atriplex halimus, Salsola vermiculata, Seidlitzia rosmarinus, and Suaeda vermiculata are encountered. These zones are dependent on the influences by humans and their grazing house animals and extraction of ground water [23]. Anabasis articulata is the most common here and has water storage in its cells and a cover of thick cuticula. Higher salt concentrations in the ground allows for this species replacement by Salsola. Salsola which has similar stems as Anabasis. Zohary (1966 pl. 246) [15] found the tumble weed Salsola kali near the Deas Sea.

Salsola vermiculata is shrubby perennial plant up to $1 \mathrm{~m}$ tall. The fruit is a 1-seeded utricle with surrounding persistent segmented calyx (sepals), extending into 5 wings. 2 minor wings have expanded limbs, and 3 are large. The largest wing lies between the 2 minor wings. Here near Azraq, Anabasis (Figure 17(a)) has mixed in Ephedra alta (Gymnosperm. Meerträubel), Atriplex halimus, also present may be Salsola tetrandra, Seidlitzia rosmarinus, Zilla spinosa, Helianthemum stipulatum, Asteriscus graveolens.

Seidlitzia rosmarinus according to Al-Eisawi (1998) [17] is a low shrub with fleshy branches and small cylindrical leaves and minute flowers in clusters of the leave axis. It is a desert plant that can tolerate salty ground.

Anabasis is characteristic to the run-off valleys of the eastern desert (Zohary 1966, pl. 259 and pl. 261 [15]) together with Anabasis articulata which occur in dry desert and Anabasis setifera found in moist saline soils in the Jordan Valley (as confirmed by Al-Eisawi (1998, Figure 93-95 [17]). Anabasis setifera as growing in weakly saline environment of Wadi Atun is a herb with green color and small size of $20-40 \mathrm{~cm}$ in height. Its stem is 


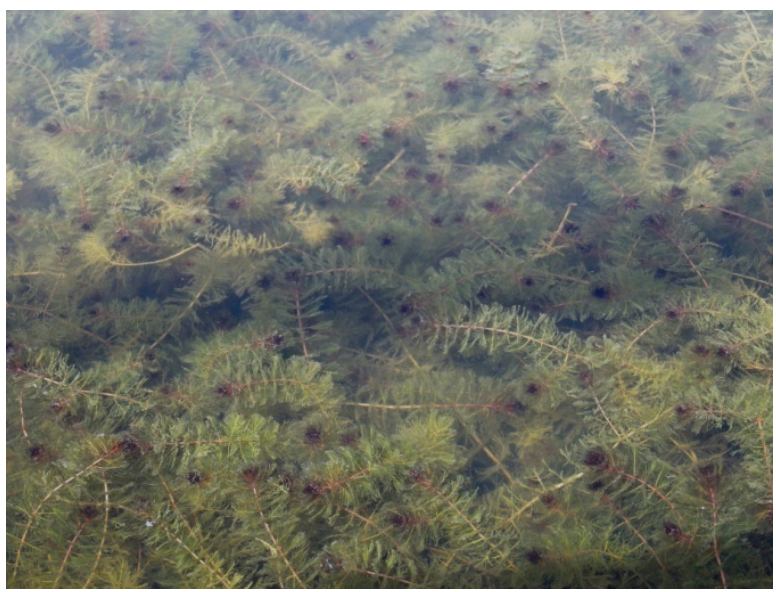

(a)

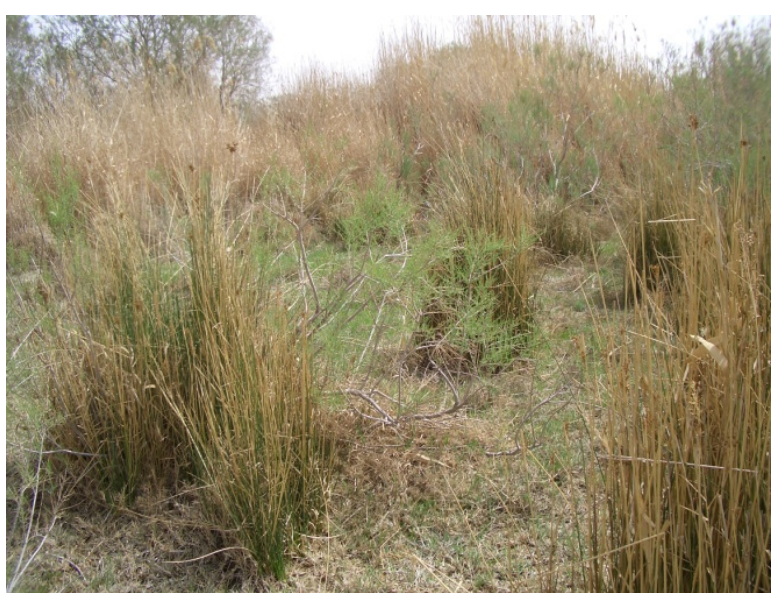

(b)

Figure 15. (a) Myriophyllum spicatum from Azraq pond 2014; (b) Juncus maritimus with Tamarix, Azraq 2014.

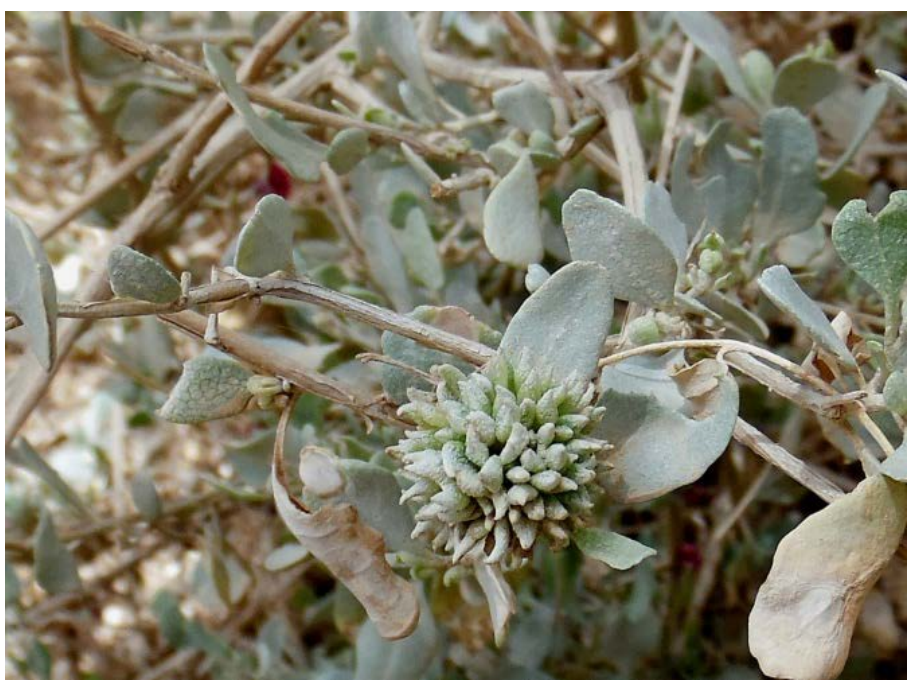

Figure 16. Nitraria retusa providing a home for insects larvae, near Azraq pool 2014.

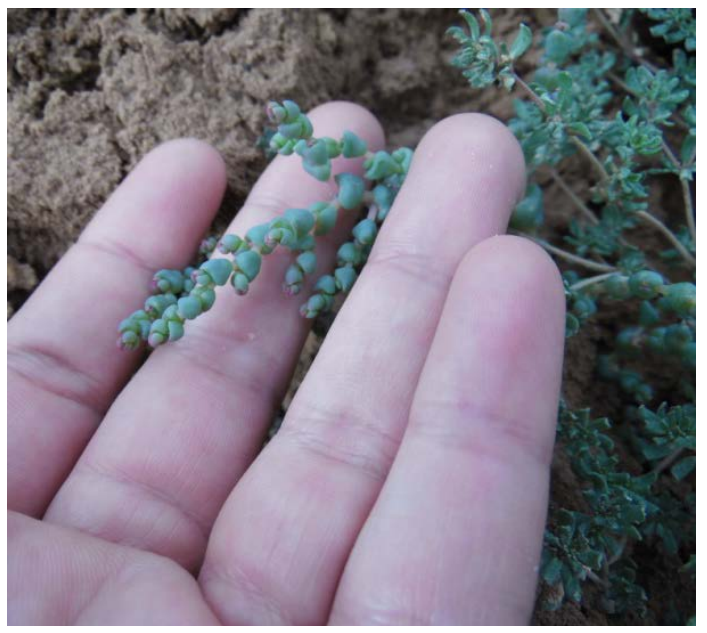

(a)

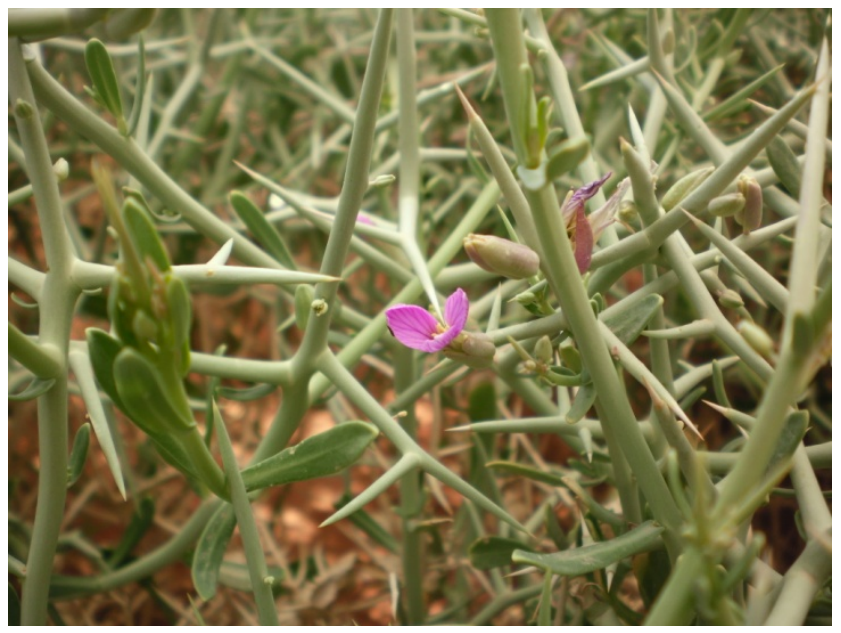

(b)

Figure 17. (a) Anabasis from the salty ground, NE Azraq, 2014; (b) Zilla spinosa in Karama 2014. 
articulated and smooth and with bushels of scales and hairs in the nodes. The leaves are reduced in size with two scale like ones at each node ending with a cureved spine. The small flowers are hermaphrodite and have both sexes together in a single plant or in groups of two to four, sunken into the leaves. Pollen and the small wingbearing fruits migrate and also disperse by wind. It occurrs in Wadi Atun with creek water salinity of about 2000 $\mu \mathrm{S} / \mathrm{cm}$. Minute insects penetrating into the young stems excrete white and sweet foamy liquid which is named by the Bedouin "mann" or "manna".

Anabasis articulata is a characteristic species of the Saharo-Arabian floral regime and grows on a wide variety of grounds also tolerating some salt (Synonym Salsola articulata). It is the dominant plant (Zohary 1966, pl. 259) [15] in the desert, but also Anabasis aphylla and Anabasis setifera occur here and have slender stems which are dry and woody in their lower part and jointed and multi branched, succulent of green color further up in the plant.

Zilla spinosa lives in hot places, for example near the Dead Sea (Zohary 1966, pl. 474) [15]. The plant forms a small bush that is very spiny and appears to be without leaves because they are small. The stems are quite regularly dichotamous in branching. The flowers are white or pink and conspicuous. It is a representative of the hot flora, found near Karama Lake (Figure 17(b)), but usually outside of areas with salty ground.

\section{Maqarin Hyperalkalin Spring}

Immediately downstream of Maqarin Dam in a side wadi of the Yarmouk River a spring issues with water salinity of about of $7000 \mu \mathrm{S} / \mathrm{cm}$ and a $\mathrm{pH}$ value of around 12.7. Here plants are resistant to hyperalkaline salty environment with Na $47.0 \mathrm{mg} / \mathrm{l}, \mathrm{Ca} 603 \mathrm{mg} / \mathrm{l}, \mathrm{Cl} 58.2 \mathrm{mg} / \mathrm{l}, \mathrm{NO}_{3} 7.2 \mathrm{mg} / \mathrm{l}, \mathrm{SO}_{4} 258 \mathrm{mg} / \mathrm{l}$, (OH) $435 \mathrm{mg} / \mathrm{l}$. Tamarix, Phragmites, Chenopodium, and Inula are noticed to grow from the alkaline mud deposited in small pools (Figure 18(a) and Figure 18(b)). Atriplex and Beta are found in the same location (Figure 19(a) and Figure 19(b)). The hyperalkalin spring is located near the bank of Yarmouk River with the coordinates: $32^{\circ} 44^{\prime} 00.6^{\prime \prime} \mathrm{N}$ $35^{\circ} 52^{\prime} 04.5^{\prime \prime} \mathrm{E}$. The water seaps through the metamorphosed 'cement' zones of bituminous rocks. In December 2014 only water animals which tolerate special conditions are present and few plants were found to tolerate that environment. Among them those present on the salty ground in the Sabkha of Azraq but not around the salty Karama Lake reservoir, with exception of Phragmites, Atriplex and Beta, all of which also grow on non-salty environments as well.

Inula crithmoides can live on salty soil and the plant as noticed by Al-Eisawi (1998) [17] grows in wet, hot places and also near the Dead Sea. Its basal stems become woody and the many green stems bear oblong spatulate leaves with toothed margin. The flower head is terminal and flowers are yellow. The plant may grow up to 1 $\mathrm{m}$ in height.

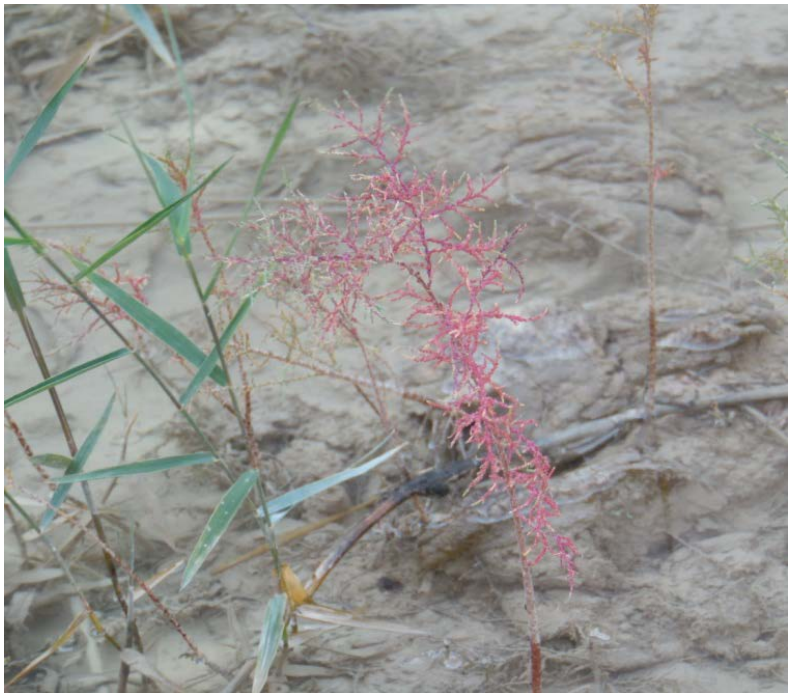

(a)

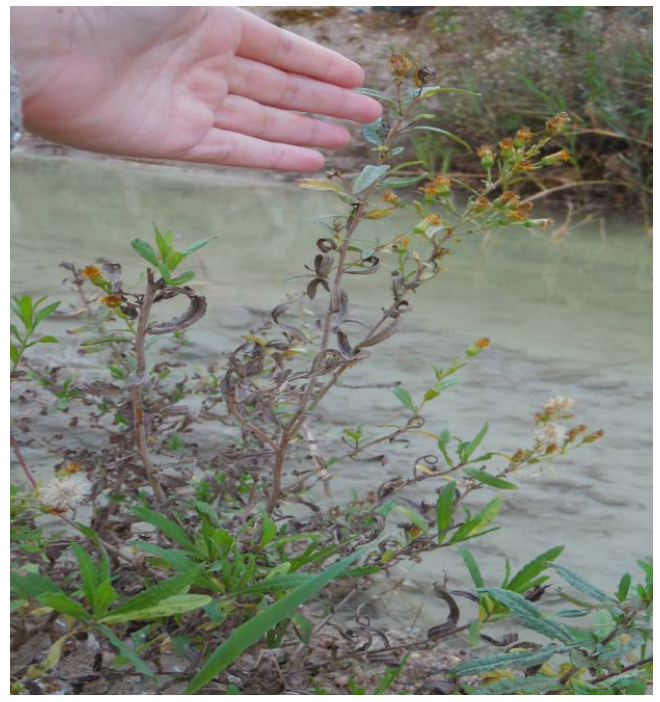

(b)

Figure 18. (a) Phragmites and Chenopodium in mud moistened by the alkaline water, Maqarin; (b) Inula crithmoides from Maqarin found together with Phragmites and Chenopodium. 


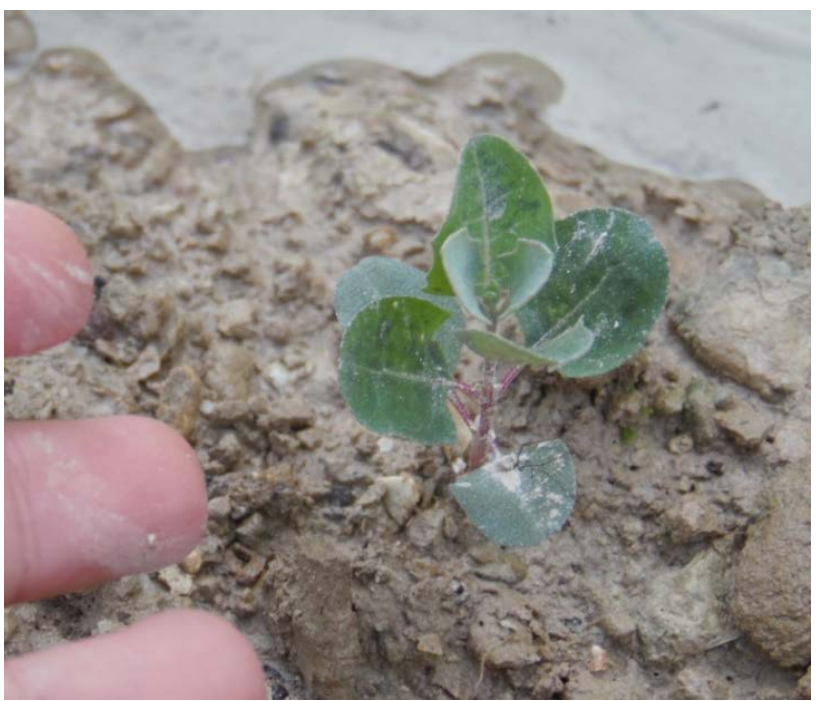

(a)

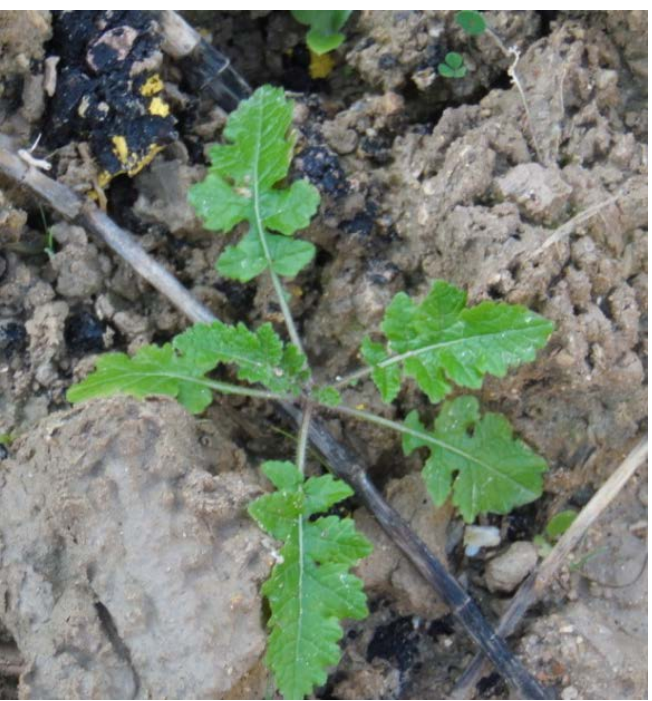

(b)

Figure 19. (a) Young plant of Atriplex, Maqarin 2014; (b) Beta growing in the alkaline mud of Maqarin, 2014.

Chenopodium has oval leaves, small green flowers, small seeds, and a very strong odor. Zohary (1966, pl. 197-202) [15] described Chenopodium album, Chenopodium ambrosioides, Chenopodium vulvaria, and Chenopodium murale from Jordan which were found to live in waste places and near irregated fields.

\section{Zarqa Valley Deep Well}

Zarqa Valley deep well is an H2S-rich artesian borehole drilled in the Mid Jurassic into Triassic rocks in the lower Zarqa Valley with a salinity of $14370 \mu \mathrm{S} / \mathrm{cm}$, a pH of 6.19, a tempreture of 35.2 and with high concentration of $\mathrm{Na}(3260 \mathrm{mg} / \mathrm{l}), \mathrm{Cl}(3930 \mathrm{mg} / \mathrm{l}), \mathrm{SO}_{4}(1050 \mathrm{mg} / \mathrm{l})$, and $\mathrm{HCO}_{3}(2155 \mathrm{mg} / \mathrm{l})$. On the soil influenced by the salty water Caryophyllaceae Spergularia, Pteranthus were found to grow (Figure 20(a) and Figure 20(b)) and Paronychia next to it on the dry ground, in addition, the composite, with yellow flower, Asteriscus grows on the moist soil and also on dry soil between rocks nearby (Figure 21(a)).

Paronychia argentea (Figure 21(b)) is an annual herb, or biennial or perennial in life span. Some species have a woody base. For the most part they have small, white to yellow-white colored flowers that are often hidden within the paired bracts.

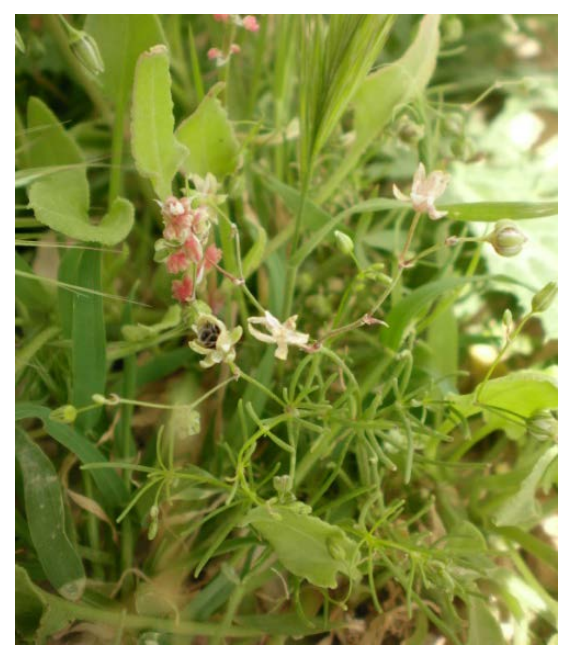

(a)

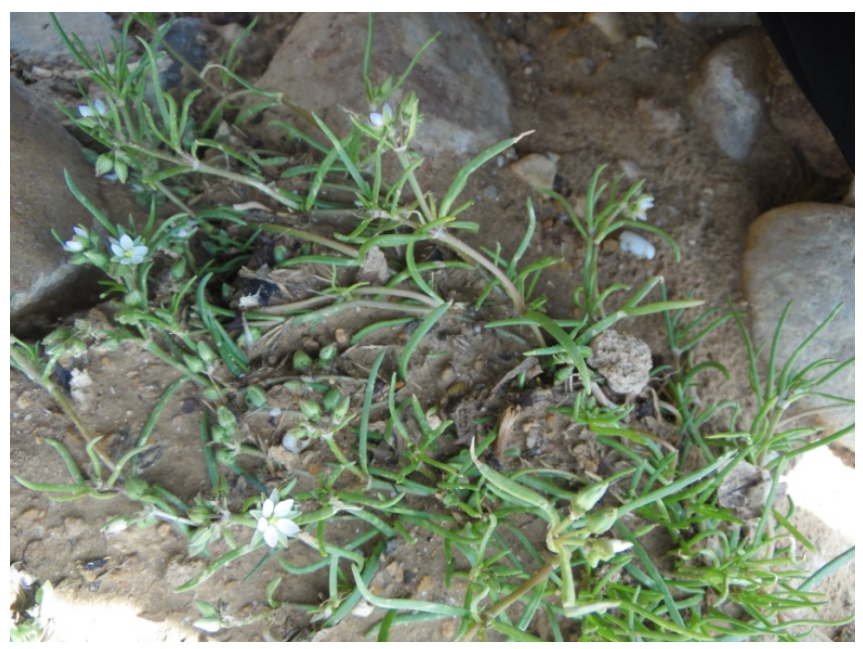

(b)

Figure 20. (a) Pteranthus, Zarqa 2014; (b) Spergularia cf diandra from the deep salty artesian well in Wadi Zarqa, 2014. 


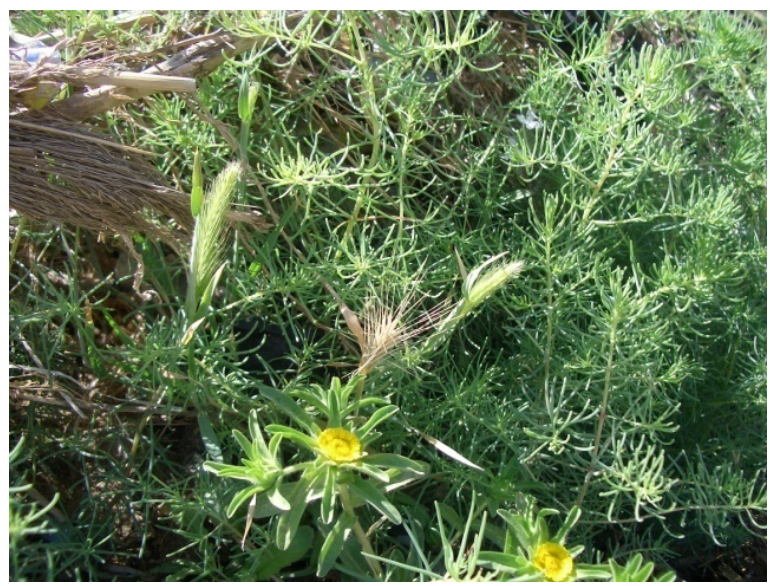

(a)

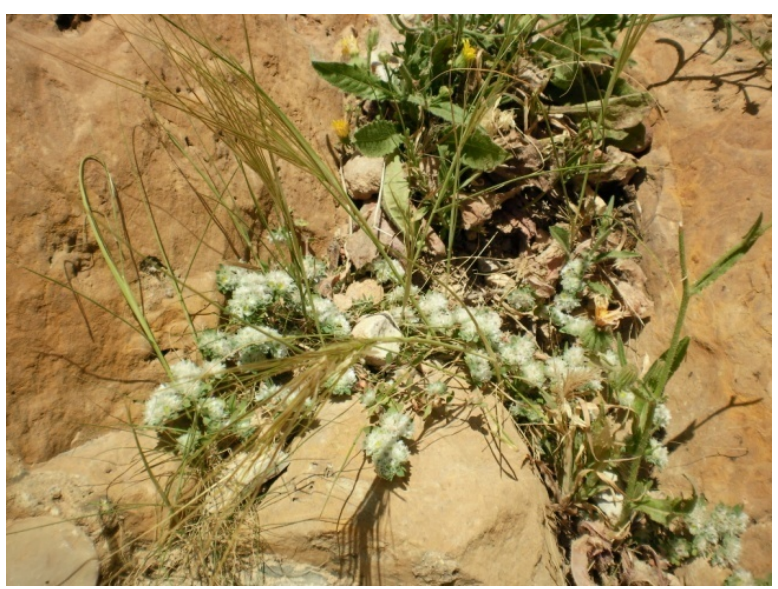

(b)

Figure 21. (a) Asteriscus with Pteranthus next to spring; (b) Paronychia from near lower Zarqa River found on rocky surface 2013.

\section{Conclusions}

Moist, but salty grounds in Jordan provide the growth regime for characteristic flora of halophytes and of plants that tolerate some salt in the ground, which also occur on non-saline grounds. The salt concentration in the ground is reflected in the composition of the flora growing on it. The plants also reflect in their species composition the type of salts. Thus sea salt type salinity, as found in the Jordan Valley surrounding Karama Reservoir Lake provides the living space for Salicornia, Suaeda, Arthrocnemum, and Mesembryanthemum, while that of Azraq Oasis sabkha is characterized by two species of Spergularia in its saltier parts and Tamarix passerinoides. All these represent obligate halophytes which in Jordan grow only on salty soils. Others are facultative halophyted which may tolerate much salinity but also occur in places which have normal salinity water available to them such as Phragmites and some Tamarix species.

A third group occurs predominantly on non-saline grounds but may tolerate some salt such as Limonium, Capparis and Asteriscus. Some prefer salty ground but enter regions with only occasional salty conditions such as Atriplex and Cressa cretica. Quite a number of species tolerate not-salty or not slightly salty ground as Asteriscus, Trigonella, Prosopis farca, Paronychia and Anthemis. A special case is the bush or small tree Tamarix in Jordan that tolerates all kinds of moist grounds. Among them Tamarix passerinoides which prefers a different type of saltyness than Tamarix tetragya and Tamarix jordanica which prefer slightly salty to fresh water, even when polluted.

Several species are facultative inhabitants of salty grounds, and these differ in relation to the studied localities. The periodically, usually only once a year flooded northern end of Karama Lake has Limonium and Asteriscus, and on its even less salty margin Atriplex and Prosopis, while the Spergularia zone in Azraq may also include Aaronsohnia and Neotorularia. On both weakly salty grounds Trigonella, Anthemis and Crepis can grow.

Degrees of saltyness are also reflected in the halophyte flora. This is quite apparent in Azraq Sabkha by the presence of Spergularia cf marina on the less saltyrim than on the lower part with Spergularia cf media. In Karama salt lake a clear sequence is seen with Mesembryanthemum on the saltiest ground, Suaeda further up and Salicornia succeeding in less salty grounds. Dryer places with rather salty grounds have bushes of Arthrocnemum, while slightly less salty places are preferred by Tamarix tetragyna. When Prosopis bushes appear, salt is only present periodically in the ground, as is the case with Atriplex halimus and Capparis.

The species of herbaceous genus Spergularia reflect the degree of saltiness in the ground by the color of their foliage. Leaves of Spergularia marina are green, while Spergularia media has often reddish color and thicken salt storage leaves. The saltier the ground the more such leaves are present on an individual plant. Salt storage in case of Mesembryanthemum is seen on all leaves when they are viewed with the magnifying glass.

Among the grasses with exception of the reed Phragmites australis, Aelurops littoralis and Juncaceae such as Juncus maritimus most others avoid salty grounds.

The plants growing on or below water, in Jordan are Ruppia in flowing brackish water in Karama reservoir and Myriophyllum in the only slightly salt bearing standing water of Azraq Lake. 
Along the Dead Sea the salt content of soils still with vegetation could be up to 7\% according to Zohary (1973) [24] who mentioned the presence of a succession of Arthrocnemum macrostachyum, Tamarix tetragyna-Nitraria retusa, succeeded by Tamarix tetragyna, Suaeda monoica, and Tamarix nilotica with Haloxylon persicum and with Atriplex halimus. Albert et al. (2004) [16] obviously relying on Frey and Kürschner (1983) [25] reported from the Dead Sea salty springs Salicornia europaea where the water is less salty, but also with increasing salinity Arthrocnemum macrostachyum, Tamarix tetragyna together with the grass Aeluropus littoralis, Phragmites australis, Juncus arabicus, next to them Suaeda aegyptiaca and Seidlitzia rosmarinus, and next may be Nitraria retusa and Suaeda monoica, and Haloxylon persicum; and Atriplex halimus. These data presented by Zohary (1973) [24], Frey and Kürschner (1983) [25] and Albert et al. (2004) [16] can be supported in general but not in details based on the localities of Azraq Oasis and Karam Reservoir. The study also concludes that Tamarix, Phragmites, Chenopodium, and Inula belong to alkaline tolerant plants group which are found in Maqarin high $\mathrm{pH}$ springs.

\section{References}

[1] Aronson, J. (1989) HALOPH: Salt Tolerant Plants for the World—A Computerized Global Data Base of Halophytes with Emphasis on Their Economic Uses. University of Arizona Press, Tucson.

[2] Flowers, T.J., Galal, H.K. and Bromham, L. (2010) Evolution of Halophytes: Multiple Origins of Salt Tolerance in Land Plants. Functional Plant Biology, 37, 604-612. http://dx.doi.org/10.1071/FP09269

[3] Jennings, D.H. (1976) The Effect of Sodium Cholride on Higher Plants. Biological Reviews, 51, 453-486. http://dx.doi.org/10.1111/j.1469-185X.1976.tb01064.x

[4] Albert, R. (1982) Halophyten. In: Kinzel, H., Ed., Pflanzenökologie und Mineralstoffwechsel, Verlag Eugen Ulmer, Stuttgart, 33-204.

[5] Flowers, T.J., Troke, P.F. and Yeo, A.R. (1997) The Mechanism of Salt Tolerance in Halophytes. Annual Review of Plant Physiology, 28, 89-121. http://dx.doi.org/10.1146/annurev.pp.28.060177.000513

[6] Popp, M. (1995) Salt Resistance in Herbaceous Halophytes and Mangroves. In: Progress in Botany, Vol. 56, Springer, Berlin, 416-429. http://dx.doi.org/10.1007/978-3-642-79249-6 19

[7] Leith, H. and Mochtchenko, D.M. (2003) Cash Crop Halophytes: Recent Studies. Kluwar Academic Publishers, London. http://dx.doi.org/10.1007/978-94-017-0211-9

[8] Jalas, J. and Suominen, J. (1980) Atlas Florae Europaeae 5: Chenopodiaceae to Basellaceae. Helsinki.

[9] Majer, B., Grummt, T., Uhl, M. and Knasmüller, S. (2005) Use of Plant Bioassays for the Detection of Genotoxins in the Aquatic Environment. Acta Hydrochimica et Hydrobiologica, 33, 45-55.

[10] Ungar, I.A. (1991) Ecophysiology of Vascular Halophytes. CRC Press, Boca Raton.

[11] Zohary, M. (1972) Flora Palestina. Part 2, Platanaceae to Umbelliferae.

[12] Sher, A.A., Wiegand, K. and Ward, D. (2010) Do Acacia and Tamarix Compete for Water in the Negev Desert? Journal of Arid Environments, 74, 338-343. http://dx.doi.org/10.1016/j.jaridenv.2009.09.007

[13] Eshel, A., Zilberstein, A., Alekparov, C., Eilam, T., Oren, I., Sasson, Y., Valentini, R. and Waisel, Y. ( 2010) Biomass Production by Desert Halophytes: Alleviating the Pressure on Food Production. In: Rosen, M.A., Perryman, R., Dodds, S., Mizi, F., Yuji, W., Polkowsaka, Z. and Sobik, M., Eds., Recent Advances in Energy \& Environment: Proceedings of the 5th IASME/WSEAS International Conference on Energy \& Environment (EE'10), WSEAS Press, Stevens Point, 362-367.

[14] Salameh, E. (2001) Water Shortage and Environmental Degradation, In: Living with Water Scarcity, Water Resources in Jordan Badia Region the Way Forwared, Al al-Bayt University, Mafraq, 71-87.

[15] Zohary, M. (1966) Flora Palestina. Part 1, Equisetaceae to Moringoceae.

[16] Albert, R., Petuschnig, B. and Watzka, M. (2004) Zur Vegetation und Flora Jordaniens. Denisia, 14, $133-220$.

[17] AL-Eisawi, D. (1998) Field Guide to Wild Flowers of Jordan and Neighbouring Countries. Jordan Press Foundation “Al Rai”, Amman, 296,488.

[18] Feinbrun-Dothan, N. (1986) Flora Palaestina. Part 4-Jerusalem.

[19] Feinbrun-Dothan, N. (1978) Flora Palaestina. Part 3-Jerusalem.

[20] Arsalan, F.A. (1976) Geologie und Hydrogeologie der Azraq-Depression (Ost-Jordanien). Unpublished Ph.D. Thesis, Technical University Aachen Germany.

[21] Salameh, E. and Al Farajat, M. (2006) The Role of Volcanic Eruptions in Blocking the Drainage Leading to the Dead Sea Formation. Environmental Geology, 52, 519-529. http://dx.doi.org/10.1007/s00254-006-0484-X 
[22] Zahran, M.A. and Willis, A.J. (2008) The Western Desert. In: The Vegetation of Egypt, Springer, Berlin.

[23] Winter, E. (1990) Characteristics and Distribution of Halophytes at a Jordanian Saltpan. Flora, 184, 341-367.

[24] Zohary, M. (1973) Geobotanical Foundations of the Middle East. Vol. 1-2, Gustav Fischer Verlag Press, Stuttgart, Swets \& Zeitlinger, Amsterdam.

[25] Frey, W. and Kürschner, H. (1983) Photosyntheseweg und Zonierung von Halophyten an Salzseen in der Türkei, in Jordanien und im Iran. Flora, 173, 293-310. 